\title{
Taşıyıcı Karton Tüp Sistemler ve Shigeru Ban Mimarlığı
}

\author{
Büşra TÜTÜNCÜ1* ${ }^{*}$, Mehmet Selim ÖKTEN²
}

Öz

Karton tüpler, odun hamurundan üretilen silindir formunda elemanlardır. Bu silindir formundaki elemanların yapı sektöründe kullanımı, kâğıdın mimaride kullanımına yönelik çalışmalarla olmuştur. Karton tüplerin farklı yapım sistemlere entegrasyonu kullanım alanlarını da genişletmiştir. Yapı sisteminin hafif, dayanıklı, ekonomik, kolay uygulanabilir oluşu, üstün yalıtım ve geri dönüştürülebilir malzeme özellikleri, deprem sonrası ortaya çıkan acil ve güvenli yapı ihtiyacı için ciddi bir alternatiftir. Yangına ve suya karşı dayanıksızlık karton tüp sistemlerin olumsuz özellikleri olarak gözükse de ilave önlemler ile bu dezavantajları gidermek mümkündür.

Çalışmada yapı sektöründe henüz yaygın kullanım yakalayamayan fakat geniş uygulama potansiyeline sahip olan karton tüp sistemler analiz edilmiştir. Karton tüp sistemlerin mimari alanda kullanımı tarihsel süreç içerisinde sistematik bir şekilde verilmiş, ardından sistemin yapım sürecine yönelik tekniklere değinilmiştir. Karton tüp sistemlerin mimari alanda kullanılmasının öncülerinden Shigeru Ban'ın yapı sektörü için önemli uygulamaları çalışma kapsamında tartışılmıştır. Ban'ın geçici deprem konutu tasarımı Düzce depremi sonrasında ülkemizde uygulanmıştır. Elde edilen verilerin alandaki Türkçe kaynak eksikliğini gidermesi, konu ile ilgili araştırmacılar için bir altyapı oluşturması beklenmektedir.

Anahtar Kelimeler: Kâğıt, karton tüp sistemler, Shigeru Ban, geçici deprem konutu

\section{Load-Bearing Cardboard Tube Systems and Shigeru Ban's Architecture}

\begin{abstract}
Cardboard tubes are cylindrical elements produced from wood pulp. The use of these cylindrical elements in the building trade has been with studies on the use of paper in architecture. The integration of cardboard tubes into different production systems has also expanded their usage areas. Light, durable, economic, easy to apply, superior insulation and recyclable material properties of the building system are important alternatives for the urgent and safe building need that emerges after an earthquake. Although weakness to fire and water appears to be the negative features of cardboard tube systems, it is possible to eliminate these disadvantages with additional precautions.

Cardboard tube systems, which have not yet been used widely in the building trade but have a wide application potential, are analyzed in the study. The use of cardboard tube systems in the architectural field has been given systematically in the historical process, and then the techniques for the construction process of the system are mentioned. The important applications of Shigeru Ban, one of the pioneers of the use of cardboard tube

\footnotetext{
${ }^{1}$ Mimar Sinan Güzel Sanatlar Üniversitesi, Fen Bilimleri Enstitüsü, Mimarlık Anabilim Dalı, İstanbul, Türkiye

${ }^{2}$ Mimar Sinan Güzel Sanatlar Üniversitesi, Mimarlık Fakültesi, Mimarlık Bölümü, İstanbul, Türkiye

*ilgili yazar/Corresponding Author: busraatutuncuu@gmail.com 
systems in the architectural field, for the building trade were considered within the scope of the study. Ban's temporary earthquake house design was applied in our country after the Düzce earthquake. It is expected that the obtained data will eliminate the lack of resources in Turkish language in the field and constitude a substructure for researchers on the subject.

Keywords: Paper, cardboard tube systems, Shigeru Ban, temporary earthquake house

\section{Giriş}

Kâğıt ilk olarak Çin'de icat edilmesine rağmen Japonya kâğıt yapım tekniklerini geliştirerek mimari alanda kullanımına öncü olmuştur. Japonya kâğıdı shoji (yarı saydam kâğıt perdeler), fusuma (kayar kâğıt paneller) ve yapının diğer bölümlerinde kullanılacak şekilde mimaride ortak bir bileşen haline getirmiştir. Japonya bu bağlamda zengin bir kâğıt kültürüne sahiptir. (Latka , 2017, s. 165).

Yapıların kolay inşa edilebilir, ekonomik ve yerel malzemeden oluşmasını savunan (1957 doğumlu) Japon mimar Shigeru Ban, kâğıdın bu özellikleri karşılıyor olması sebebiyle kâğıt tüplerin strüktürde kullanımına dair çalışmalar yürüten öncü isimdir. Ban, kâğıt tüpleri ilk kez, 1985'te Finli mimar Alvar Aalto anısına düzenlenen sergide kullanmıştır. Ban, hem sınırlı bütçesinden dolayı hem de Aalto tarafından kullanılan temel malzemelerden biri olan ahşaba atıfta bulunmak istediğinden, sergiler arasında kâğıt tüpler kullanmaya karar vermiştir (Latka, 2017, s. 173).

Ban, sergi sonrası kâğıt tüplerin mimaride yapısal unsur olarak kullanılma olasılığını incelemek adına harekete geçmiştir. Bunun üzerine endüstriyel ortamda üretilen kâğıt tüplerin hem direncini hem de zorlu iklim koşullarına karşı davranışını saptamak amacıyla kâğıt tüpleri çeşitli testlere tabi tutmuştur. Tüm bu çalışmaların sonucunda kâğıt tüplerin kalıcı yapılarda ilk kullanımı, 1991 yılında inşa edilen "Şair Kütüphanesi" olmuştur (Latka , 2017, s. 173).

Karton tüplerin ana bileşeni kâğıtlardır. Selülozik liflerden oluşan kâğıdın, yan ürünlerinin ve bu ürünlerin en önemlilerinden biri olan kartonun en büyük avantajı ekonomikliği, hafifliği, dayanıklılığı, şekil, renk olarak esnek ve geri dönüştürülebilir olmasıdır (Campean vd., 2020, s. 10) (Schonwalder, 2016, s. 12).

Yaygın kullanılan yapı malzemelerinden olan beton ve çeliğe göre daha ekonomik ve rahat temin edilebilir olması, özel işgücü gerektirmemesi karton tüpleri alternatif bir yapı malzemesi yapmaktadır. Karton tüplerin, termal ve akustik yalıtım özelliklerine sahip olması, kolay dönüştürülebilir ve yenilenebilir kaynaklardan oluşturulabilmesi sistemi ayrıca avantajlı kılmaktadır. Yapı elemanı olarak kullanılabilen oluklu mukavva biçimi ise yüksek derecede yapısal mukavemete ve sertliğe sahiptir (Campean vd., 2020, s. 10).

Dünyada birçok ülkenin deprem ve yıkıcı etkisinden yılda en az bir kere etkilendiği göz önüne alındığında ise sistemin yüksek mukavemete ve sertliğe sahip olması karton tüplerin yapılarda kullanımına yönelik büyük bir potansiyele sahip olduğunu göstermektedir. Ülkemiz, dünyanın en önemli deprem kuşaklarından olan Alp-Himalaya deprem kuşağı üzerinde yer aldığı için son 60 yılda doğal afetlerden dolayı oluşan hasarların \%61'ine depremler neden olmuştur (Bikçe, 2017, s. 26). Kayıplar açısından değerlendirildiğinde ise ortaya çıkan tablo 1900-2014 yılları arasındaki istatistik verilerine göre; 81 ilin 55'inde (\%68) can kaybı ve/veya hasardır (Bikçe, 2016, s. 1414). Can ve mal kaybının artmasına sismik konum, toplum bilincindeki yetersizlik, kontrolsüz ve hızlı büyüme, denetim sorunları, deprem standartlarına uygun yapı tasarımı yapılmaması gibi 
faktörlerin yanı sıra yapı ve yapı malzemelerinin istenen düzeyde üretilememesi gibi sorunlar depremin yıkıcı etkisini artıran unsurları oluşturmaktadır.

Yapılarda yaygın kullanım yakalayan beton ve çeliğin standartların altında üretilerek, öngörülenin dışında uygulanması can ve mal kaybını artırıcı en önemli unsuru oluşturmaktadır. Özellikle beton malzemedeki teknik eksikliklerden olan mıcır ve kumun beton içerisindeki boyut ve miktarının yeterli düzeyde olmaması, çimento ve/veya çimento/su oranındaki dengesizlikler, yerinde dökme beton yöntemlerinin hava koşullarından etkilenmesi ve donatıların planlanandan farklı konumlandırılması (Bikçe, 2017 , s. 27) gibi temel unsurlar beton malzemenin yapılarda kullanımına risk oluşturmaktadır. Öte yandan karton tüp sistemler, fabrika ortamında prefabrike olarak üretilir ve yüksek teknolojiye intiyaç duymazlar. Basit teknik unsurlarla yüksek kalite standartlarına erişimi karton tüplerin yapısal bir bileşen olarak kullanımda öne çıkaran özelliklerdendir. Sık deprem etkisine maruz kalan ülkelerden olan Japonya, bu özelliklerin yanı sıra malzemenin bünyesinde barındırdığı hafiflik etkisini kullanarak depremin yıkıcı etkisini azaltmayı başarmıştır.

Karton tüp sistemlerin neme, yangına, sıcaklığa ve çeşitli ışıklara karşı hassasiyeti dezavantajları olarak değerlendirilse de bu olumsuzlukları sızdırmaz malzeme kullanımı, kaplama, laminasyon ve emprenye gibi uygulama teknikleri ile gidermek mümkündür. Bahsedilen tekniklere ve malzemenin geliştirilmesi için yapılan birçok çalışmaya rağmen karton tüp sistemlerin yapısal eleman olarak mimari alandaki kullanımı yaygınlaşmamıştır.

$\mathrm{Bu}$ çalışmanın amacı karton tüp sistemlerin yapı sektörüne katkılarını ve sınırlarını değerlendirmektir. Bu sebeple sistemin hangi intiyaçlar doğrultusunda ortaya çıktığı, gelişimi, olumlu ve olumsuz yönleri değerlendirilmiştir. Değerlendirme sırasında bu alandaki en önemli isimlerden biri olan Shigeru Ban'ın örneklerine yer verilmiştir. Çalışma sonuçlarının deprem etkisinin sıkça görüldüğü ülkemizde daha önce acil konut intiyacı için uygulanmış alternatif bir sistemin tekrar değerlendirilmesini sağlaması ve araştırmacılar için bir altyapı oluşturması beklenmektedir.

\section{Karton Tüp Sistemlerin Gelişimi}

Literatürde karton tüp sistemler, kâğıt tüp sistemler olarak da geçmektedir. Her ikisinin de yapısı fiziksel anlamda birbirinden farklı değildir. Kâğıt, bitkisel liflerin özel aletlerle dövülmesi ve karıştırılması sonucu, liflerin keçeleşmesi, saçaklanması, su emerek şişmesi ve mekanik etkilerle kesilmesinden sonra süzgeç (elek) üzerinde oluşumu neticesinde belirli bir sağlamlık kazanan düzgün malzeme olarak tanımlanabilir. Karton ise çok katlandırılmış, sert dayanıklı ve kalın kâğıt malzemedir. İkisi arasındaki fark metrekare ağırlıklarıdır (Tüfenk, 1989, s. 1).

10-150 gr/m² ağırlığındaki ürünler; kâğıt

151-400 gr/m² ağırlığındaki ürünler; karton olarak isimlendirilir.

Tüp sistemlerde de metrekare ağırlığına göre kâğıt ya da karton kullanılabilmektedir.

Kâğıt, Çin İmparatorluğu'nun nazırlarından olan Cai Lun tarafından M.S. 2. yüzyılda icat edilmiştir. Çin kâğıdı temel işlevi olan yazı yazma amacı dışında mimaride iç mekânda sabit seperatör eleman olarak da kullanmıştır ve hatta bu iç mekândaki sabit seperatör kullanımı kâğıdın bölücü sistemlerde gelişiminin temelini oluşturmuştur. Çin'de iç mekânda sabit bölücü olarak kullanılan kâğıt, daha sonraki yılarda Japon geleneksel evlerinde hafif ahşap şeritli yapısal iskelete sahip hareketli mekân bölücüleri olan shoji (yarı saydam kâğıt perdeler), fusuma (opak kayar kâğıt paneller) olarak evrilmiştir. Bu 
durum, geleneksel Japon evlerindeki tek hacim olarak ele alınan mekânların çok amaçlı kullanımını sağlamış ve günümüz mekân çözümlemelerine kaynaklık etmiştir (İçemer, 2015, s. 7) (Kurnalı, 2015, s. 54).

Geleneksel Japon evlerinin tüm bileşenleri standart ölçülerde kullanılmaktadır. Shoji de diğer Japon evi bileşenleri gibi standart ölçülerdedir (Şekil 1). Genişliği sütun mesafesine, yüksekliği ise evin yatay ve dikey modüler düzenine tabi olan üst-alt raylar arasındaki mesafeye göre belirlenmektedir (Engel, 1985, s. 112)
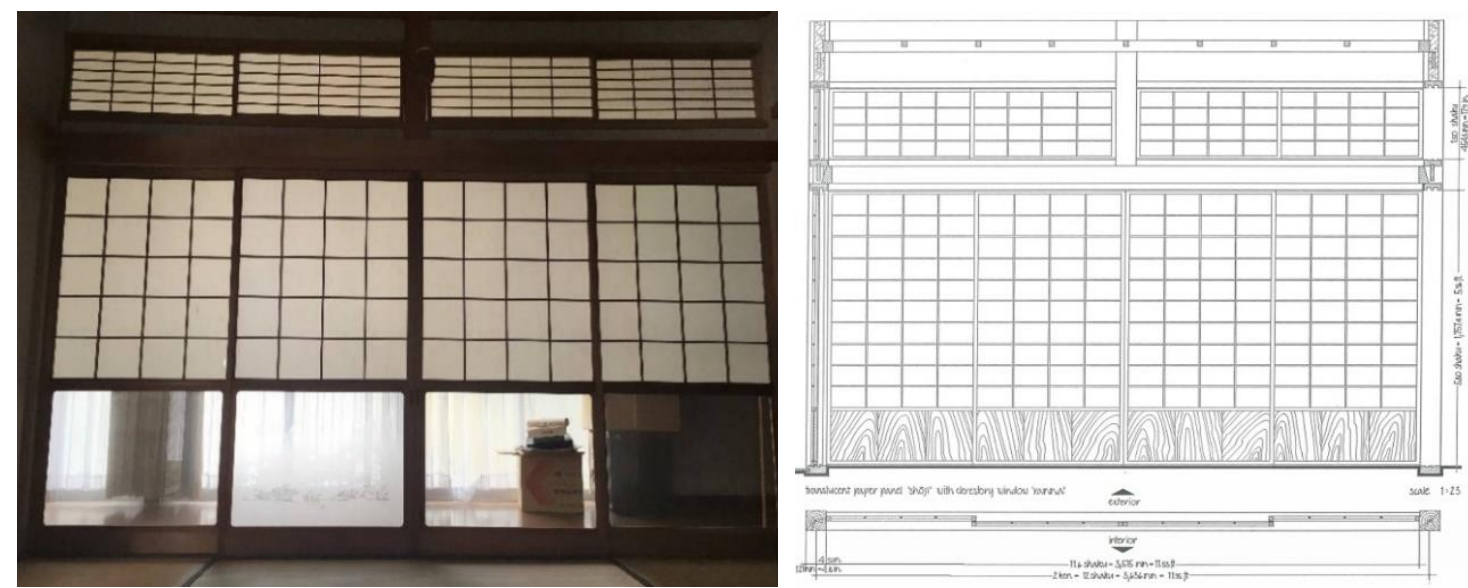

Şekil 1: Geleneksel Japon mimarisinde shoji (solda), teknik çizim gösterimi (sağda) (URL-1) (Engel, 1985, s. 114)

Geleneksel Japon evlerinde mekânı bölücü bir eleman olarak kullanılan kâğıt, bölücü eleman olmanın yanı sıra oda kapısı gibi yapısal bir bileşen olarak da kullanılmaktadır. Yapısal bileşen olarak yapılarda kullanımına izin veren opak kayar kâğıt paneller fusuma olarak adlandırılmaktadır (Şekil 2). Shojiye hafif ahşap şeritli çerçeve elemanlarıyla desteklenmesi açısından benzerlik göstermektedir. Ancak shoji yapısal ahşabın bir tarafına yarı saydam kâğıt yapıştırılmasıyla oluşturulurken; fusuma da yapısal ahşap çerçevenin her iki tarafı opak kâğıtlarla kaplanmaktadır. Yapısal ahşap çerçevede dikkat çeken faktör ise shojiye benzer olarak aşırı hafifliktir (Engel, 1985, s. 117,119).
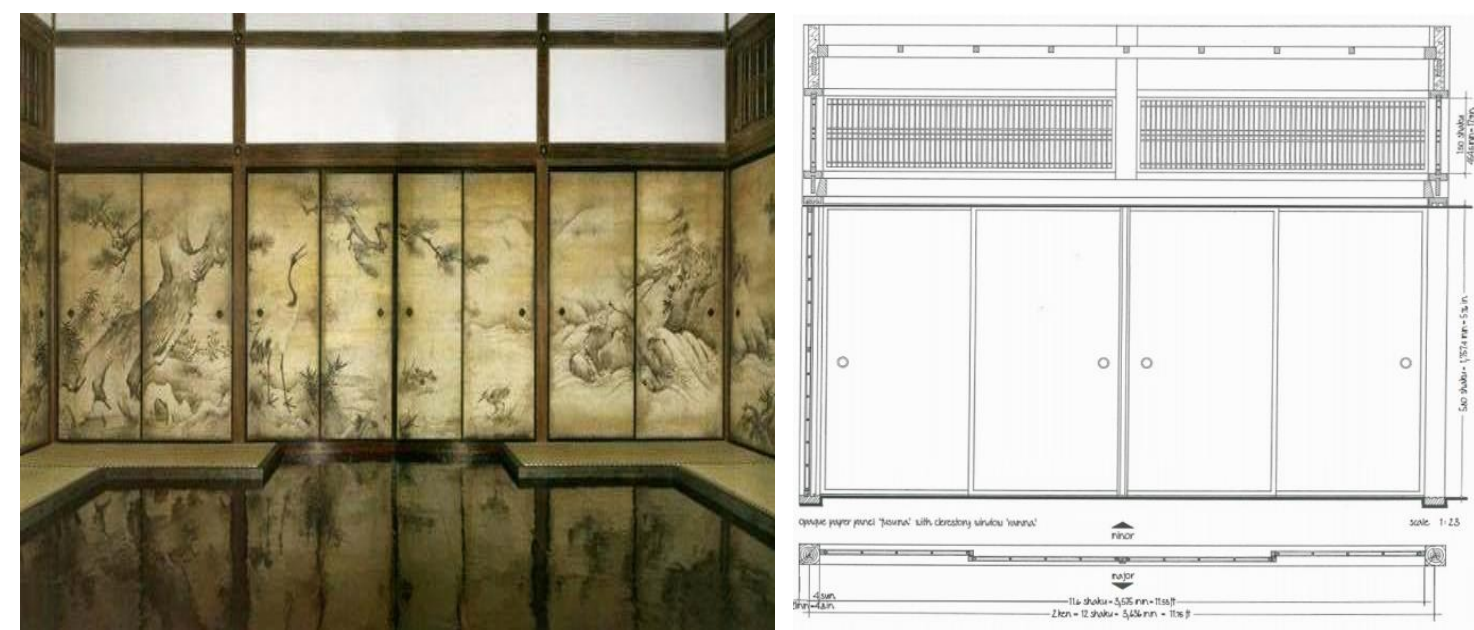

Şekil 2: Geleneksel Japon mimarisinde fusuma kullanımı (solda), teknik çizim gösterimi (sağda) (URL-2) (Engel, 1985, s. 117)

18.yy'da Fransız Nicholas-Louis Robert ilk "sürekli kâğıt" üreten makineyi yapmıştır. Bu makine geniş bir kayışın dönerek fıçıdaki hammadde lapasını aldığı ve ince bir kâğıt 
haline getirdiği, her dönüşte sadece bir kâğıt üretebilen basit bir makinedir (Akpınar, 2011, s. 1). "Seri kâğıt" üreten makinenin icadının üzerinden çok geçmeden, (1809 yılında) John Dickinson, silindirli makineyi icat etmiştir. Zaman içerisinde artan makineleşme ve sanayileşmeye rağmen kâğıt yapımındaki ana yöntem değişmemiştir. Kâğıdın hammaddesi olan bitkisel lifler, nemli bir ortamda birbirine bağlanmasının ardından preslenir ve kurutulur. Üretim yöntemi kolay bir malzemedir. Gelinen nokta gelişen teknolojinin etkisiyle, kâğıt üretiminin tam otomatik şekilde yapılabildiğidir. Liflerin elde edilmesinde ana kaynak ağaçlar olsa da sentetik lifler de günümüzde kullanılmaktadır

Kâğıt-karton üretimi, kâğıt hamurunun (selüloz) hazırlanması, hazırlanan hamurun üretim öncesi işlemleri ve üretim bölümlerini içermektedir (Şekil 3).

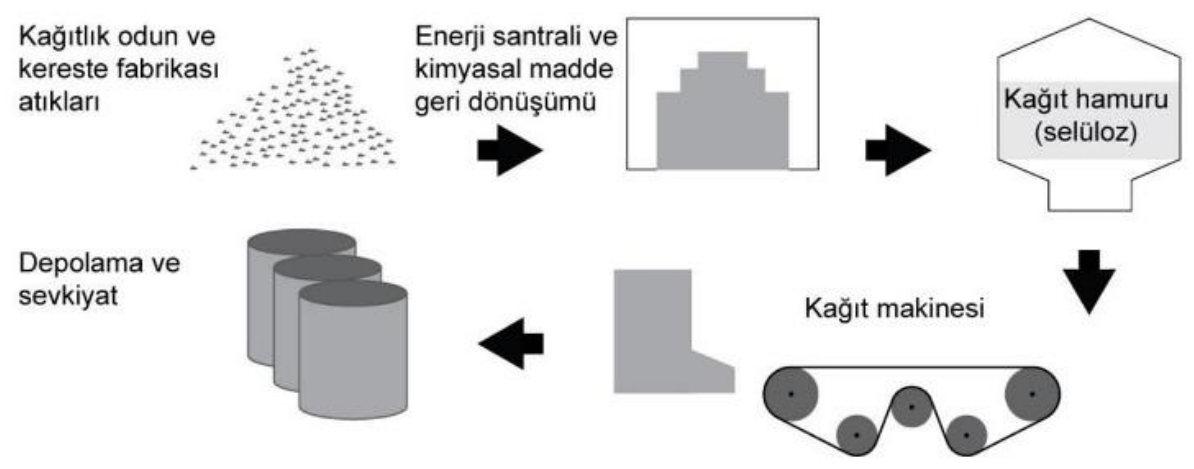

Şekil 3: Kâğıt üretim şeması (Akpınar, 2011, s. 1)

Günümüzde makineler aracılığıyla tam otomatik olarak gerçekleşen üretim bölümü sayesinde üretimden kaynaklı hataların önüne geçilebilmektedir. Ayrıca son yıllardaki makineler, daha seri ve yüksek kapasiteli olduğu için elde edilen ürünler kalite ve süreklilik bakımından geçmiş teknolojilere göre üst seviyededir.

Malzemede bahsedilen gelişmeler doğrultusunda kâğıdın mimari alandaki gelişimini gösterebilmek için yapısal uygulamalardan örnekler tarihsel sıra içinde Şekil 4'te sunulmuştur.

1867'de kalıcı yapı kullanımına yönelik inşa edilen ilk prefabrik karton yapılar, ev ve hastane olmak üzere farklı fonksiyonlara ve boyutlara sahiptir (Şekil 4). Paris Dünya Sergisi'nde sergilenen kâğıt ev ve hastanenin boyutları birbirine hemen hemen yakınken, sıcak iklime sahip ülkeler için tasarlanan kâğıt evde ise daha farklı bir konfigürasyon olan 5x20m boyutları kullanılmıştır (Latka, 2017, s. 167).

1871 'de kâğıdın ondüle bir şekilde ambalaj malzemesi olarak kullanılışı kâğıt endüstrisi için yeni gelişmelere sebep olmuştur. Oluklu mukavvanın ABD'de patentlenmesinin ardından mühendisler, karton ve oluklu mukavvayı yapı bileşeni olarak denemeye başlamışlardır.

Kalıcı yapılarda kâğıt kullanımının en eski örneklerinden biri Rockport, Massachusetts, Elis F. Stenman tarafından ABD'de inşa edilen bir evdir (Şekil 4). 1922'de yapımına hobi olarak başlanan ev 1924'te tamamlanmıştır. Yapı ahşap bir çerçeveden oluşmaktadır. Zemini ve çatısı da ahşaptır. Duvarları ise doldurulan ve verniklenerek preslenen gazete kâğıtlarıdır. Yapı içerisindeki mobilyalar, piyano ve şömine haricinde kâğıttan yapılmıştır. Fakat piyano ve şöminenin de kâğıtla kaplanmasıyla bütüncül bir tasarım oluşturulmuştur. Yapının doksan yıldan uzun süredir kullanımına devam edilmektedir. Uygun ve düzenli bakımlarla kâğıdın dayanıklılığı uzun ömürlü olabilmektedir (URL-3). 


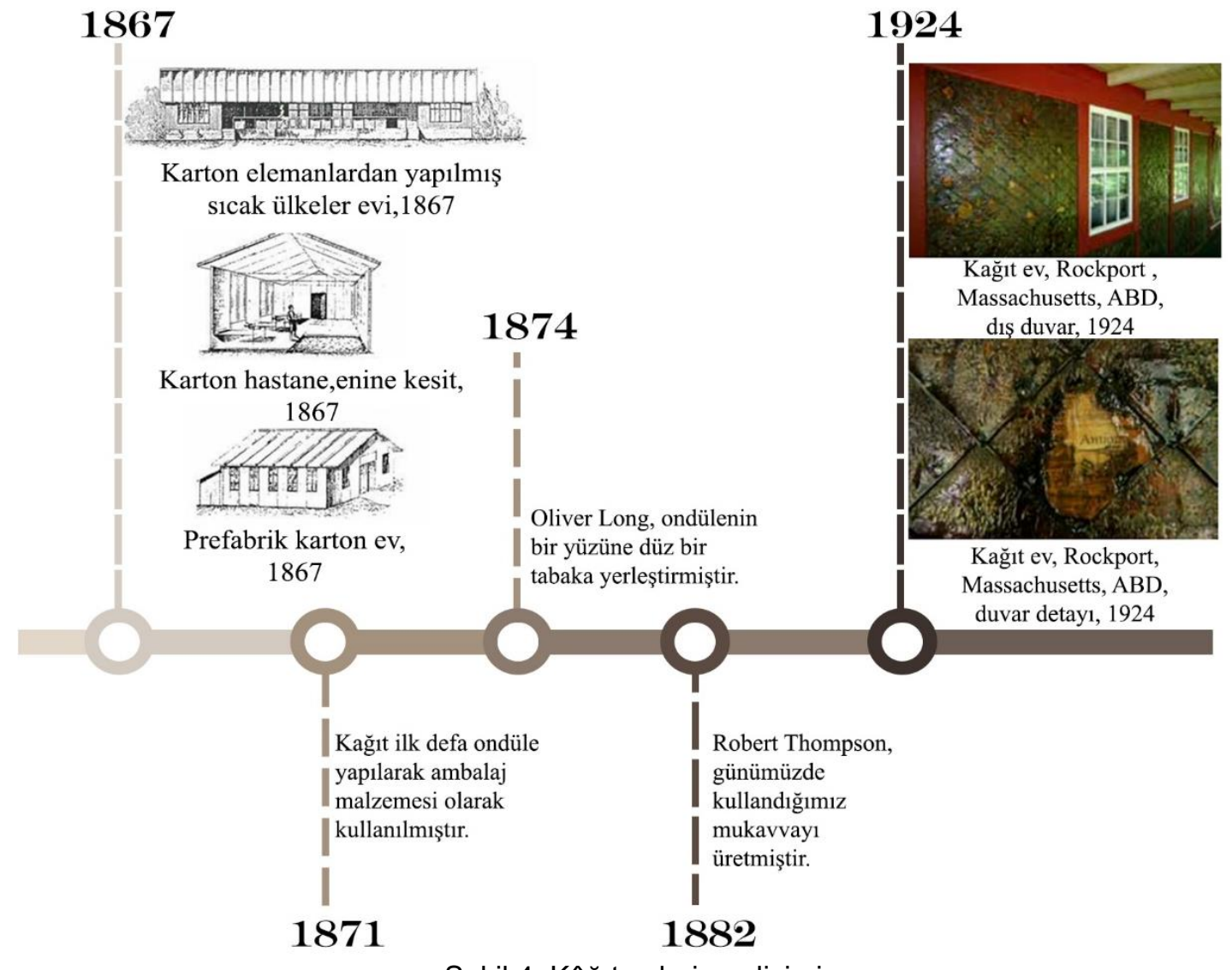

Şekil 4: Kâğıt evlerin gelişimi

Kâğıdın mimaride kalıcı kullanımına yönelik denemelerin ardından barınaklarda da kullanımına başlamasıyla, malzeme geçici yapılarda gelişimini sürdürmüştür (Şekil 5). Bu şekilde kâğıt hem geçici hem de kalıcı yapılarda denenerek, yapı sektöründe kendini hissettirmeye başlamıştır.

1944 yılında Kâğıt Kimya Enstitüsü, karton malzemeye sülfür emdirerek taşınabilir deneysel bir barınak yapısı tasarlamıştır (Şekil 5). Bir saat içerisinde bir kişi tarafından kurulabilen yapının duvarları $25 \mathrm{~mm}$ kalınlığındaki kâğıt plakalardan oluşmaktadır. Kartonların üzeri yanmaz boya ile kaplanmıştır. Bir yıl süre için yapılan bu barınak, 20 yıldan fazla süre ayakta kalmayı başarabilmiştir ve ağırığı 500kg'dır (Latka , 2017, s. 168).

1957 yılında, yaptığı özgün çalışmalarla modern mimarlık fikirlerini etkileyen Richard Buckminster Fuller ve Montreal McGill Üniversitesi öğrencileri dışı alüminyum levha kaplı karton kutulardan jeodezik kubbe formunda, çapı 9,5m olan bir yapı inşa etmişlerdir (Şekil 5).

1962-1964 yılları arasında poliüretan köpük panellerle lamine edilmiş karton kullanımı üzerine araştırmalar yapılmıştır (Latka , 2017, s. 169). Araştırılan bu ürünü test etmek için üçgen kesitli çerçeveler oluşturulmuştur. İki katlı bir yapıda yapılan gerilme deneyleri sonucunda ürünün mukavemetinin yeterli olduğu saptanmıştır.

1966 'da Sanford Hirshen ve Sym van der Ryn tarafından Kaliforniya'daki mevsimlik çiftlik işçileri için antiprizmatik katlanmış plaklardan oluşan ve "Plydom" adı verilen binden fazla konaklama birimi tasarlanmış ve inşa edilmiştir (Şekil 5). Oldukça ekonomik olan 
katlanabilir birimlerin, katlanmamış halindeki plan boyutları 5,15x5,80m'dir. Mukavemetini paralel şekilde katlanan plakların eğilme rijitliğinin artması sonucunda kazanan birimlerde, malzeme olarak her iki yüzünde $10 \mathrm{~mm}$ kalınlığında masif levha bulunan, içi poliüretan köpük dolgulu sandviç paneller kullanılmıştır. Levhalar suya karşı dayanıklılık açısından polietilenle kaplanmıştır (Karni \& Pellegrino, 2007, s. 93) (Latka , 2017, s. 170).

1971 yılında, Steve Bear tarafından Baer Zome House projesi olarak tasarlanan ev, solar pasif evin en eski örneklerindendir. Yapının duvarları, iki tarafı ince alüminyum kaplama ile lamine edilmiş $50 \mathrm{~mm}$ kalınlığında açılabilen karton petek panellerden oluşmaktadır (Şekil 5). Duvarların bir kısmında kerpiç bloklar kullanılmıştır (Baer, 2009, s. 7) (Latka , 2017, s. 170).

Hong Lee ve John Gibson tarafından 1974 yılında prefabrik bir acil durum sığınağı için prototip geliştirilmiştir (Şekil 5). Altı ay boyunca Galler'de sergilenen yapının bir benzeri ilerleyen yıllarda da inşa edilmiştir. Üç adet oluklu mukavva tabakasının birbirine cıvata veya zımbalarla tespit edilmesiyle oluşturulan yapı, 3,6m yüksekliğe ve $7,2 \times 2,4 m^{\prime}$ lik bir plana sahiptir. Kaliforniya Politeknik Eyalet Üniversitesi'nde, 1977 yılında acil durum yapıları için öğrenci önerileri kapsamında yapılan bir etkinlikte yapı sergilenmiştir (Şekil 5) (Latka , 2017, s. 171).

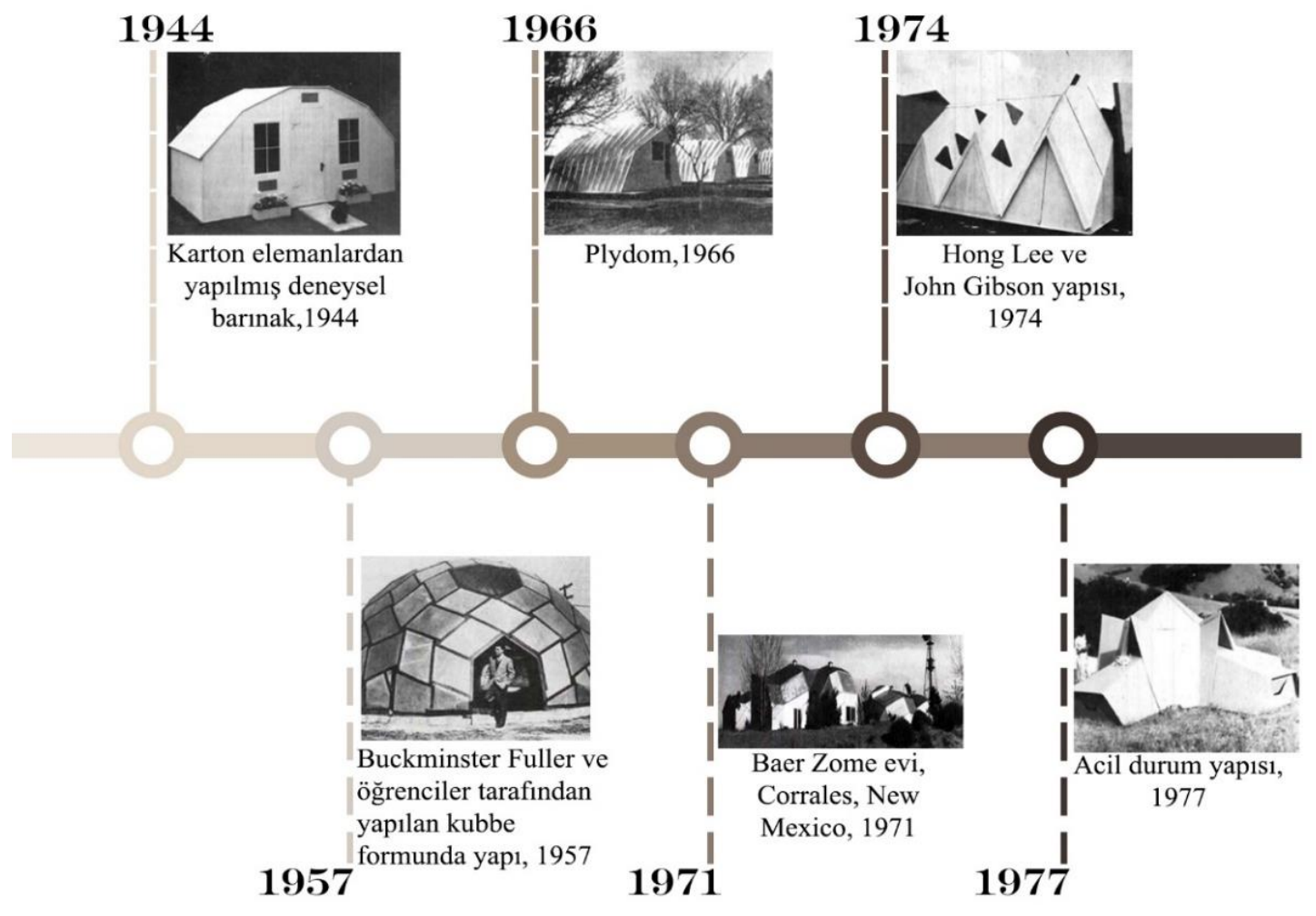

Şekil 5: Kâğıt barınakların gelişimi

Mimaride kâğıt kullanımın gelişimi farklı deneysel yaklaşımları ortaya çıkarmıştır. Kâğıdın makinede üretimi, oluklu mukavva ve petek panellerin bulunuşu kâğıdın mimaride kullanımında önemli bir rol oynamıştır. Özellikle İkinci Dünya Savaşı sonrası Amerika ve Avrupa'da yaşanan konut sıkıntısının yanı sıra savaş sonrası askerlerin evlerine dönmeleri ve göçmenler için düşük bütçeli konutlara yeni malzeme ve uygulamalara verilen destek, mimaride kâğıt ve karton kullanımını alternatif bir malzeme 
yapmış ve geçici barınma ihtiyacını karşılamak için kullanılmıştır. Süreç içerisinde mimarlar tarafından denenen çalışmalar da mimaride kâğıt ve karton kullanımı açısından bir ilgi oluşturmuştur. Kâğıdın dönüştürülebilir olması dolayısıyla malzemenin ikincil hammadde olarak yapı sektörüne katılabilme özelliği, kâğıdı bu süreçte daha popüler kılmıştır. Ancak modern anlamda kâğıdın yapı sektörüne girişi, 1980 sonrası sürdürülebilir malzemelere olan ilginin artmasıyla gerçekleşmiştir. Shigeru Ban'ın 1995 yılında uygulanan karton tüp sistemli Ban's Paper House projesi ile kâğıt kalıcı olarak inşa edilmiştir. Ban'ın bu projesi kâğıdın mimaride kullanımı açısından dönüm noktası olmuştur.

\section{Taşıyıcı Karton Tüplerin İmalatı}

Karton tüplerin üretiminde intiyaçların doğru belirlenmesi, stabil çözümler ve maliyet açısından önem arz etmektedir. Karton borular, farklı endüstrilerde çok çeşitli işlevler için kullanılmakta ve tipik olarak, istenen boyutlarda bir mandrel etrafına sarılmış karton şeritlerden imal edilmektedir (URL-4). Karton tüplerin imalatında; intiyaçların belirlenmesi, üretim süreci, kesim işlemi ve paketleme/nakliye olmak üzere toplam 4 adım izlenmektedir.

\section{1 İhtiyaçların belirlenmesi}

Malzemenin bir tüpün içinde veya bir çekirdeğin dışında sarılması gibi iki şekilde üretilebilen karton tüplerin tasarımlarında etkili olan 7 parametre bulunmaktadır (URL-4);

Dayanım- Bir tüpün dayanım-ağırlık oranı çeşitli faktörlere bağlıdır. Kullanılan kâğıt cinsi, yapıştırıcılar, katmanlama, reçineler, kürleme ve tüpün uzunluğu karton tüpün dayanımını etkiler. İstenilen dayanım değerlerini elde etmek için karton tüp üreticisiyle birlikte çalışılmalı ve gerekli mekanik değerler önceden belirlenmelidir.

Uzunluk- Genel olarak yaklaşık 1,2m uzunlukta üretilen karton tüpler, isteğe göre herhangi bir uzunlukta üretilebilir.

Iç Çap Ölçüsü- Karton tüpler sadece iç çap ölçülerine göre tanımlanmıştır, çap ölçüsü tüpün dışından alınmamaktadır. Yapılacak uygulama için özel bir dış ölçüye intiyaç varsa, hatalardan kaçınmak için üreticiyle dikkatli bir şekilde iletişim kurulmalıdır.

Cidar Kalınlığı- Bir karton tüpün cidar kalınlığını, kullanılan kâğıt malzemesinin cinsi ve katman sayısı belirlemektedir. Reçineler, yapıştırıcılar ve diğer kaplamalar da karton tüplerin cidarlarının son kalınlığını etkilemektedir.

Üretim Maliyeti- Dayanımı yüksek karton tüplerin üretimi daha maliyetlidir. Bu tip üretimlerde sistemin ağırlığı da artacağı için dayanım-ağırlık oranı optimum olan üretimleri hedeflemek maliyet açısından en ekonomik çözümdür.

Ağırlık- Ağırlığın özellikle düşük tutulması gerekiyorsa, dayanım ve diğer mekanik özellikler için standartları karşılayan en hafif tüpü oluşturmak üzere en iyi malzeme ve işlem kombinasyonunu bulmak için üreticiyle birlikte çalışılmalıdır.

Sızdırmazlık Malzemeleri veya Kürler- Karton tüplerin neme dayanıklı, su geçirmez veya üretildikleri temel kâğıt malzemelerden daha esnek olması isteniyorsa, gözeneksiz bir malzeme oluşturmak için üretim sırasında uygulanan özel sızdırmazlık maddelerine ve işlemlere intiyaç duyulmaktadır. 


\section{2 Üretim Süreci}

Teknisyenlerin üretim makinelerini ayarlaması üretim sürecinin ilk aşamasıdır. Makine operatörlerinin istenilen ürün özelliklerini sağlayan karton tüpü oluşturmak için kartonun mandrel boyutu ve katlarını ayarlayarak makineleri hazırlaması ise bir sonraki aşamadır (Yazoo Mills, 2019, s. 3). Bu hazırlıklar üretim standına geçmeden önce ayırma ve yapıştırma stantlarında gerçekleşen uygulamalardır.

Ayırma standında gerçekleşen aşamalar sırasıyla aşağıda verilmiştir (Şekil 5).

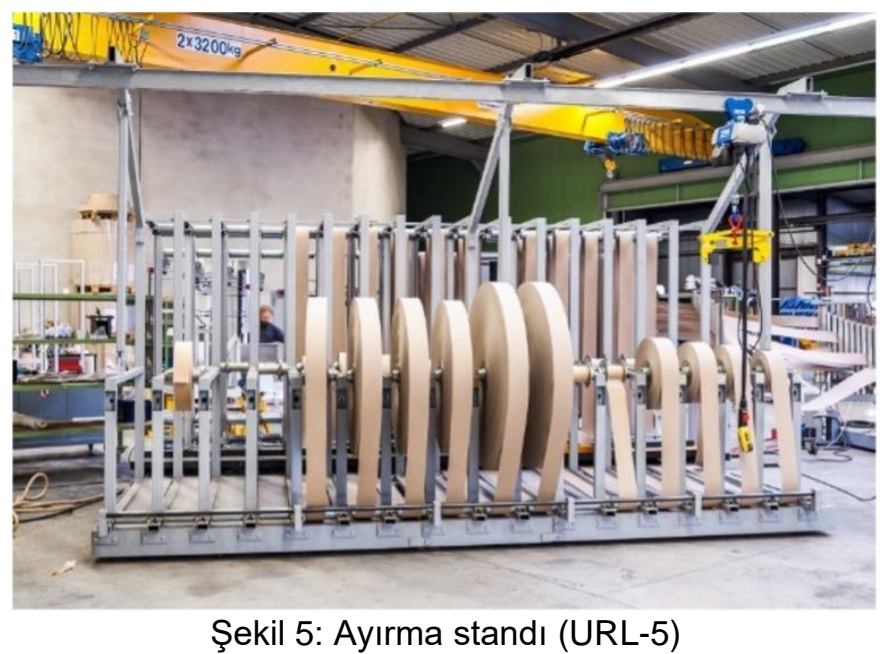

- Büyük kâğıt rulolar ayırma standına alınır.

- Dönen kayışlar kâğıtları belli boyutlarda ayırır.

- Boyutlandırılan kâğıt, istenilen iç çap ölçüsünü oluşturmak için mekanik bir bağlantı vasıtasıyla üretim standına aktarııır.

Yapş̧ırma standında gerçekleşen aşamalar ise aşağıda verilen sıra ile uygulanmaktadır (Şekil 6);

- Üretim standına geçmeden önce kâğıtların her katına yapıştırıcı uygulaması yapılmaktadır. Yapıştırıcılar, tüp üreticilerinin kendi tescilli formüllerinden oluşmaktadır.

- Su ve mukavemete karşı polivinil kaplama bu aşamada uygulanabilmektedir. Karton tüpleri yalıtmanın kaplama, laminasyon ve kâğıt hamurunun emprenye edilmesi gibi farklı yolları mevcuttur. Kaplama işlemi karton tüplerin polietilen, reçine, vernik, biyo-polimer ve balmumu gibi ürünlerle ıslatılarak, sıcak preslenerek, Isıyla kaynaştırılarak, püskürtülerek veya boyanarak uygulanmasıdır. Laminasyon işlemi, kâğıt malzemenin polietilen folyo, poliüretan köpük ve polivinil klorür folyolar ile birleştirilmesiyle oluşan sandviç tekniğidir. Geri dönüşüm açısından yapıştıııcı olarak kullanılan malzemeye önem verilmelidir. Kâğıt hamurunun emprenye edilmesi ise üretim sürecinde kâğıt hamuruna eklenen malzemelerle kütlenin yalıtılma işlemidir. Bunların dışında kâğıt, kanvas veya ateşe dayanıklı, su geçirmez farklı malzemeler ile de kaplanabilmektedir.

- Kâğıtlar rijitlik açısından belirli bir doğrultuda yerleştirilmektedir.

- Dakikada 160m kâğıdı sarabilecek kapasitede olan kayışların (Şekil 6'daki gri kayışlar), düzeneği çalıştırmak için gerilmesi ve sürekli bir sarım yapacak şekilde döndürülmesi gerekmektedir.

- Düzeneğin bir tarafından giren kâğıtlarla borunun iç çapı, diğer tarafından giren kâğıtlarla da üst katman oluşturulmaktadır. 

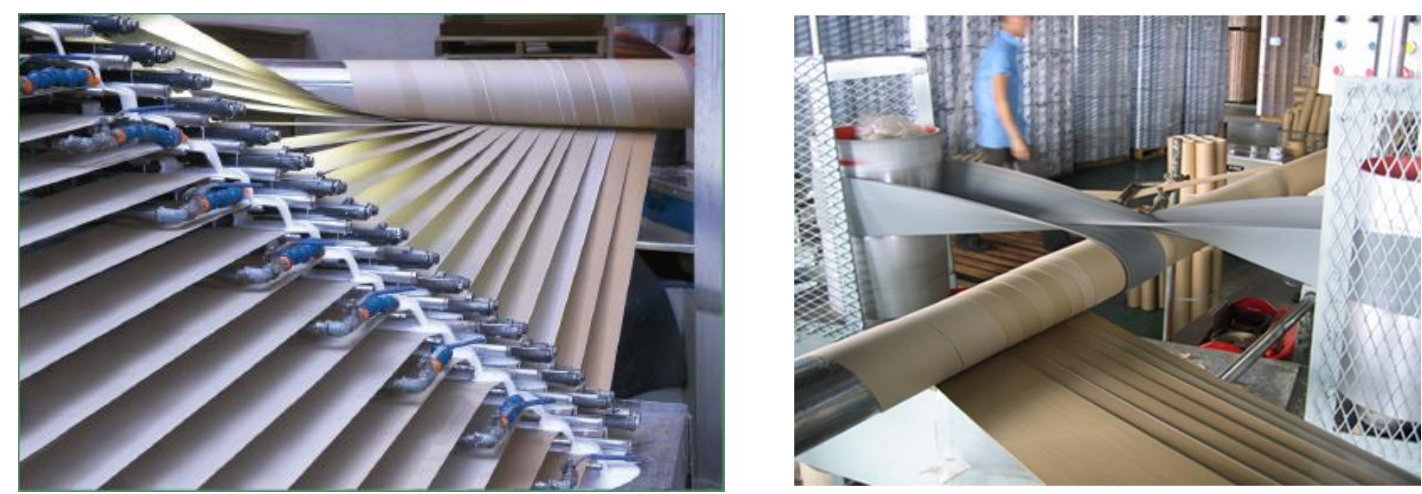

Şekil 6: Yapıştırma ve üretim standı (URL-6) (URL-7)

\subsection{Kesim işlemi}

İmalatın üçüncü adımını kesim işlemi oluşturur. Üretimi tamamlanan karton tüp, kesim standında istenen uzunlukta kesilmektedir (Şekil 7). Yapıştırıcılar, tüplerin üretiminden hemen sonra kesime geçebilmesine izin verecek priz süresine sahiptir.
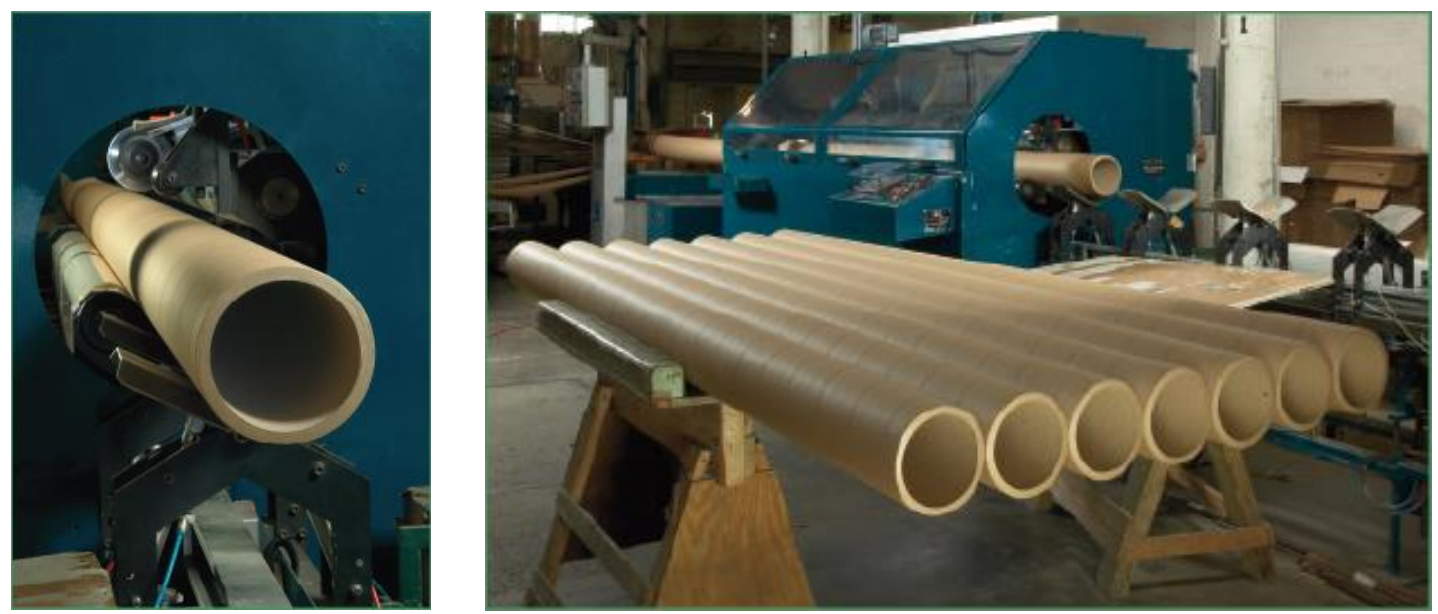

Şekil 7: Kesim standı (URL-6)

\subsection{Paketleme/nakliye}

Dördüncü ve son adım ise paketleme ve nakliyedir. Karton tüpler, gelişen teknolojiyle birlikte otomatik olarak paketlenebilmektedir. Paketlemede karton tüplerin iç çap ölçüsü ve uzunluğu önem taşır. Nakliye sırasında karton tüplerin hasar görmemesi için sürecin doğru planlanması gerekmektedir (Şekil 8).

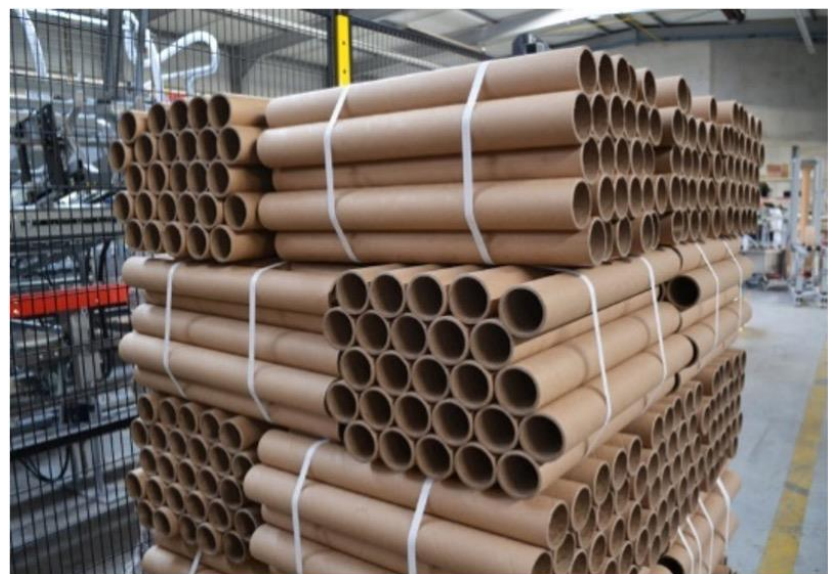

Şekil 8: Paketleme (URL-8) 


\section{Taşıyıcı Karton Tüplerin Kullanım Alanları}

Karton tüpler veya kâğıt tüpler sunta, mukavva, kraft kâğıt ve kâğıt-yapışkan kompozitler gibi farklı karton çeşitleri haline getirilmiş odun hamurundan üretilen silindirik ürünlerdir (URL-4).

Karton tüpler, yapı sektöründe hem inşaat mühendisliği alanında hem de mimaride kendine yer edinmiştir. Yapım sürecinde strüktürel elemanlar olan kolon, kiriş, kemer, kafes ve çerçevelerde kullanılmaktadır. Ayrıca betonarme kalıplarda da kullanımı mevcuttur (Şekil 9).
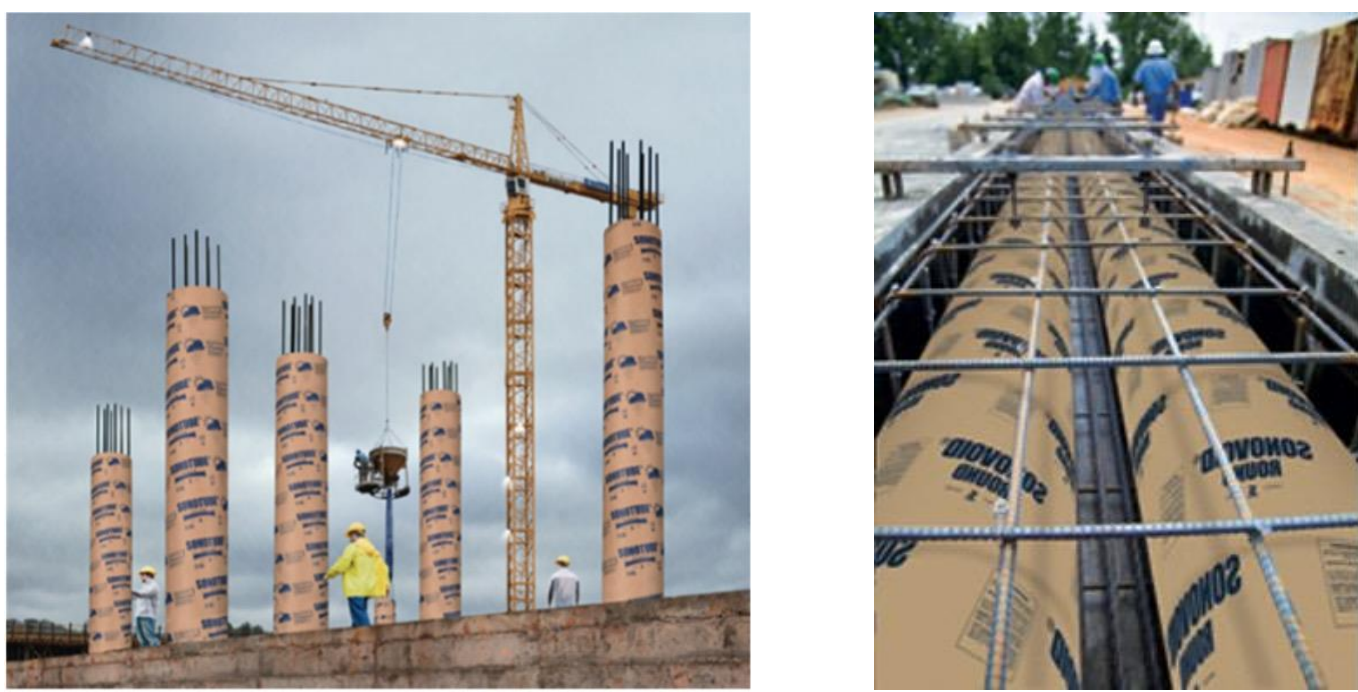

Şekil 9: Karton tüplerin betonarme kalıplarda kullanımı (URL-9) (URL-10)

\subsection{Taşıyıcı karton tüplerin kolon olarak kullanımı}

Kolon olarak kullanılan karton tüpler eksenel basınç yüklerine maruz kalmaktadır (Şekil 10). Eksenel basınç yüklemesi altında, karton tüpün gerilme-şekil değiştirme eğrisi doğrusal değildir ve maksimum yüke yaklaştıkça malzeme önemli ölçüde yumuşar. Üretimde kullanılacak dayanım değerleri tipik olarak maksimum yükün \%20 ila \%30'u arasında belirlenir. Göçme maksimum basınç yükü kapasitesinin \%85 ila \%90'u arasında tüpün dış katmanın kırışmasıyla başlar (Bank \& Gerhardt, 2016, s. 467).

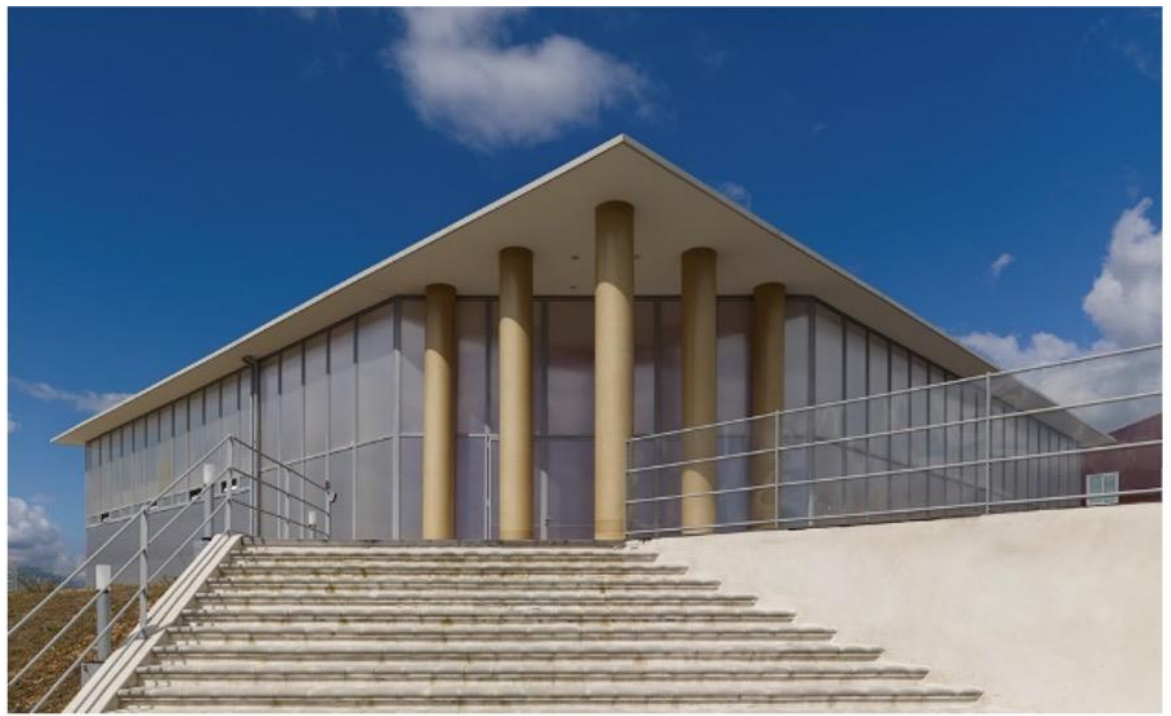

Şekil 10: Taşıyıcı karton tüplerin kolonlarda kullanımı (URL-11) 
Karton tüpü bir kolon (veya herhangi bir başka yapısal eleman) olarak kullanmak için, üzerine etkiyen yüklerin diğer yapısal elemanlara veya temellere aktarımı güvenli bir şekilde sağlanmalıdır. Mesnet bölgesinin güvenliği, tüpün içinde veya dışında teşkil edilen genellikle ahşaptan yapılmış birleşim elemanları kullanılarak rahat bir tasarım ile gerçekleştirilir. Birleşim elemanlarının tespitinde vidalar ve çelik cıvatalar kullanılır (Bank \& Gerhardt, 2016, s. 467).

Bağlantı noktalarındaki toplam yükün vidalar veya cıvatalar arası eşit dağıldığı varsayılır. Karton tüp kolonların boyutları, iç çap ölçüsü $76 \mathrm{~mm}$, cidar kalınlığı $12 \mathrm{~mm}$ 'den başlamakta ve iç çap ölçüsü 550mm, cidar kalınlığı 100mm'ye kadar çıkmaktadır.

\subsection{Taşıyıcı karton tüplerin kiriş olarak kullanımı}

Kirişler yatay olarak açıklık geçen, kendi ağırıkları ile ölü ve hareketli yükleri taşıyan yapı bileşenleridir. Karton tüplerin düşük elastisite modülü ve eğilme rijitliği (EI) sebebiyle yatay kiriş elemanı olarak kullanımında küçük ölçekli yapılar tercih edilmektedir (Şekil 11). Dolayısıyla karton tüp kirişlerin üzerine etki eden ölü ve hareketli yükler mümkün olduğu kadar minimize edilerek kirişin kendi ağırlığı altında sehim yapmadan kısa ve uzun dönemde durması amaçlanmaktadır. Kirişlerin bağlantı detayları kolonlara göre daha karmaşıktır.

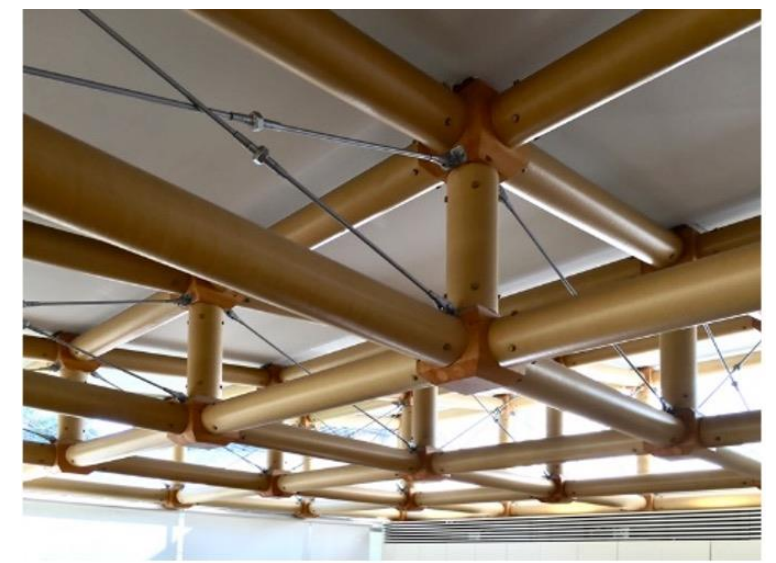

Şekil 11: Taşıyıcı karton tüplerin kirişlerde kullanımı (URL-12)

\subsection{Taşıyıcı karton tüplerin kemer, kafes ve çerçeve olarak kullanımı}

Sistemin eğilmeye karşı hassasiyeti büyük açıklıklar geçmek amacıyla kemerler ve kafes kirişler gibi eksenel kuvvetler altında çalıştırılan yapı formları ile ilgili denemeleri ortaya çıkarmıştır (Şekil 12). Karton tüpler kolaylıkla bükülebildiği için kemer uygulamalarında imalat safhasında bükülme ve form verme işlemi yapılabilmektedir.

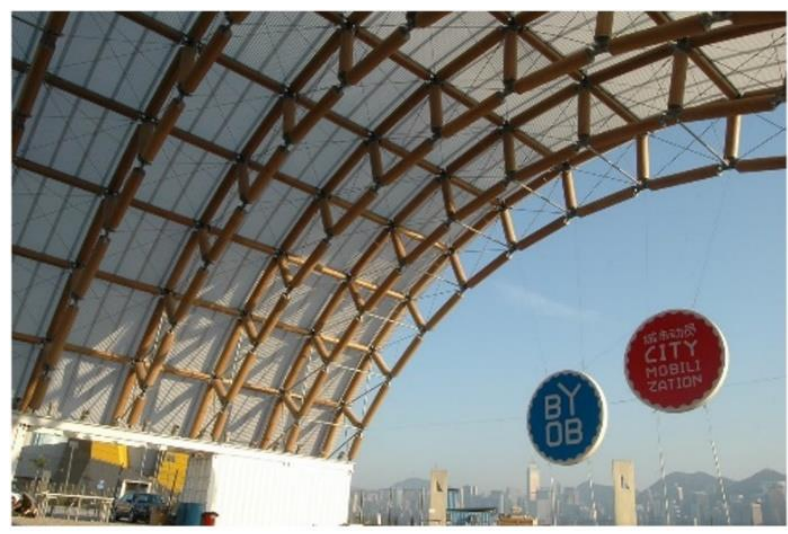

Şekil 12: Taşıyıcı karton tüplerin kafes yapım sistemiyle kemer formunda kullanımı (URL-13) 
Kolon ve kirişlerden oluşturulan çerçeve sistemlerde küçük açıklıklar tercih edilmelidir. Çerçevenin yatay yüklere karşı dayanımı için çapraz eleman kullanılamadığı durumlarda moment aktaran rijit birleşimler yapılmaktadır. Kolonun temele mesnetlendiği bölgede tüpe nem girmemesi için özen gösterilmelidir. Kesilen tüp uçlarının epoksi ile kaplanması ve kapatılması veya karton tüpün geçirimsiz bir plastik kaplama ile kapatılması tavsiye edilmektedir (Bank \& Gerhardt, 2016, s. 471). Bununla birlikte malzemenin durabilite özelliklerini artıran bu uygulamaların yüzde yüz geri dönüşüme olumsuz etkileri olmaktadır.

\section{Taşıyıcı Karton Tüplerde Shigeru Ban Yapıları}

Shigeru Ban, 1957 yılında Tokyo'da doğmuştur. Küçük yaşlardan itibaren sanata ilgisi vardır. Güney Kaliforniya Mimarlık Enstitüsü'nden mezun olmuş ve mimarlık hayatına geleneksel Japon mimarisinden etkilenerek başlamıştır. Shigeru Ban, çevreye karşı duyarlılığıyla birlikte yenilenebilir malzemeleri kullanarak farklı strüktürler oluşturmayı başarmıştır. Özellikle kâğıdı karton tüp olarak mimaride kullanması, malzemenin mimaride çağdaş kullanım sürecini başlatmıştır. Yalıtılmış karton tüpleri farklı sistemlerle bütünleştirmesi, gelenekseli modernle yorumlama yaklaşımı olarak değerlendirilmektedir.

Ban, "Afet Yardım Projeleri" ile sosyal problemlere de eğilmiştir. Bu amaçla 1995 yılında "VAN: Voluntary Architects Network" (Gönüllü Mimarlar Ağı)" isimli sivil toplum örgütünü kurmuştur. Farklı fonksiyonlarda afet yardım projelerinde bulunmuş ve çalışmalarından dolayı 2014'te Pritzker Mimarlık Ödülü'ne layık görülmüştür.

Çalışma kapsamında karton tüplerin mimarideki dönüm noktaları olan Shigeru Ban yapılarından örnekler verilmiştir. Ayrıca mimarın ülkemizde uygulanan geçici barınak yapılarından "geçici kâğıt ev" projesine de değinilerek kapsam genişletilmiştir.

\subsection{Odawara salonu ve doğu kapısı, Odawara, Kanagawa, Japonya, 1990}

Odawara Belediyesi'nin kuruluşunun 50. yılına özel inşa edilmiştir (Şekil 13). Yerel yönetimin tercihi ahşap bir yapıyken, maliyet ve süre engelinden dolayı iç ve dış duvarlarda kâğıt tüpler kullanılmıştır. Çatı konstrüksiyonunda çelik tercih edilmiştir. Yaklaşık $1300 \mathrm{~m}^{2}$ büyüklüğünde bir iç mekâna sahiptir. 330 adet kâğıt tüpten oluşmaktadır. Tüplerin çapı 525mm, kalınlığı $15 \mathrm{~mm}$ ve uzunluğu $8 \mathrm{~m}$ 'dir (URL-14).
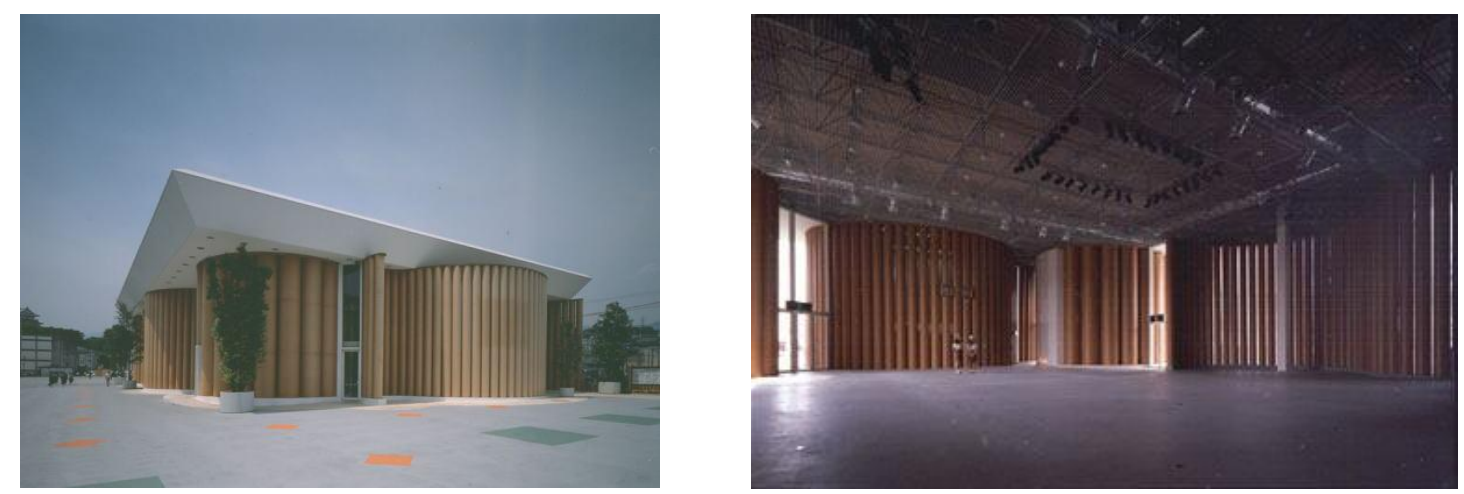

Şekil 13: Odawara Salonu, Odawara, Kanagawa, Japonya, 1990 (URL-14)

\section{2 Şair Kütüphanesi, Zushi, Kanagawa, Japonya, 1991}

Mevcut bir yapıya ek olarak tasarlanan kütüphane, konut sahibinin 1990 yılında inşa edilen Odawara Pavyonu'nu görmesi sonucunda kâğıt türevli ek yapının, kütüphane işlevi için uygun olabileceği görüşüyle inşa edilmiştir (Şekil 14). 
Odawara Pavyonu'nda çatısında kullanılan karton tüp makasların benzeri bu yapıda da tercih edilmiştir. Duvarlarda kullanılan karton tüpler $100 \mathrm{~mm}$ çapında, $12,5 \mathrm{~mm}$ kalınlığında olup açıklıklarda ard germeli çelik halatlar kullanıımıştır (Şekil 14). Farklı sıcaklık ve nem değerlerinde duvarlarda oluşan sünme etkisini araştırmak üzere duvarlar bir yıl süre ile teste tabi tutulmuştur. Sabit yük altında meydana gelen plastik(kalıcı) deformasyon olarak tanımlanan sünme etkisi, yapı elemanlarında kullanılabilirliği etkileyebileceği gibi hasara ve çökmelere de neden olabilir. Bu etkinin araştırılması için de $400 \mathrm{~mm}$ uzunluğunda üretilen karton tüp duvar numunesi iki plaka arasına yerleştirilerek, karton tüpün maksimum basınç dayanımının üçte biri olan $29 \mathrm{~kg} / \mathrm{cm}^{2}$ gerilme değerinde çelik çubuklar kullanılarak sıkıştırılmıştır. Bir yıl boyunca duvarlardan ve numuneden haftada bir ölçümler alınmıştır. Test sonuçları sıcaklık ve nem farklılıklarından dolayı karton tüplerde deformasyon oluştuğunu, sünme etkisinden kaynaklanan deformasyonların ise minimum düzeyde gerçekleştiğini göstermiştir. Karton tüp sistemlerin atmosferik etkilerden korunduğu zaman yapısal olarak önemli bir parametre olan sünme etkisine karşı dayanıklıı̆̆ı taşıyıcı sistem açısından önemli bir davranıştır. Kütüphanede boyuna doğrultuda beton zeminden tavana kadar yükselen, konsol 4 adet büyük kitap rafı mevcuttur. Karton tüplerden bağımsız olarak çalışan bu raflar yapının yatay yüklere karşı dayanımını sağlamaktadır. Bununla birlikte kitap raflarının dışında yalıtım uygulaması bulunmaktadır (Latka , 2017, s. 176-177).
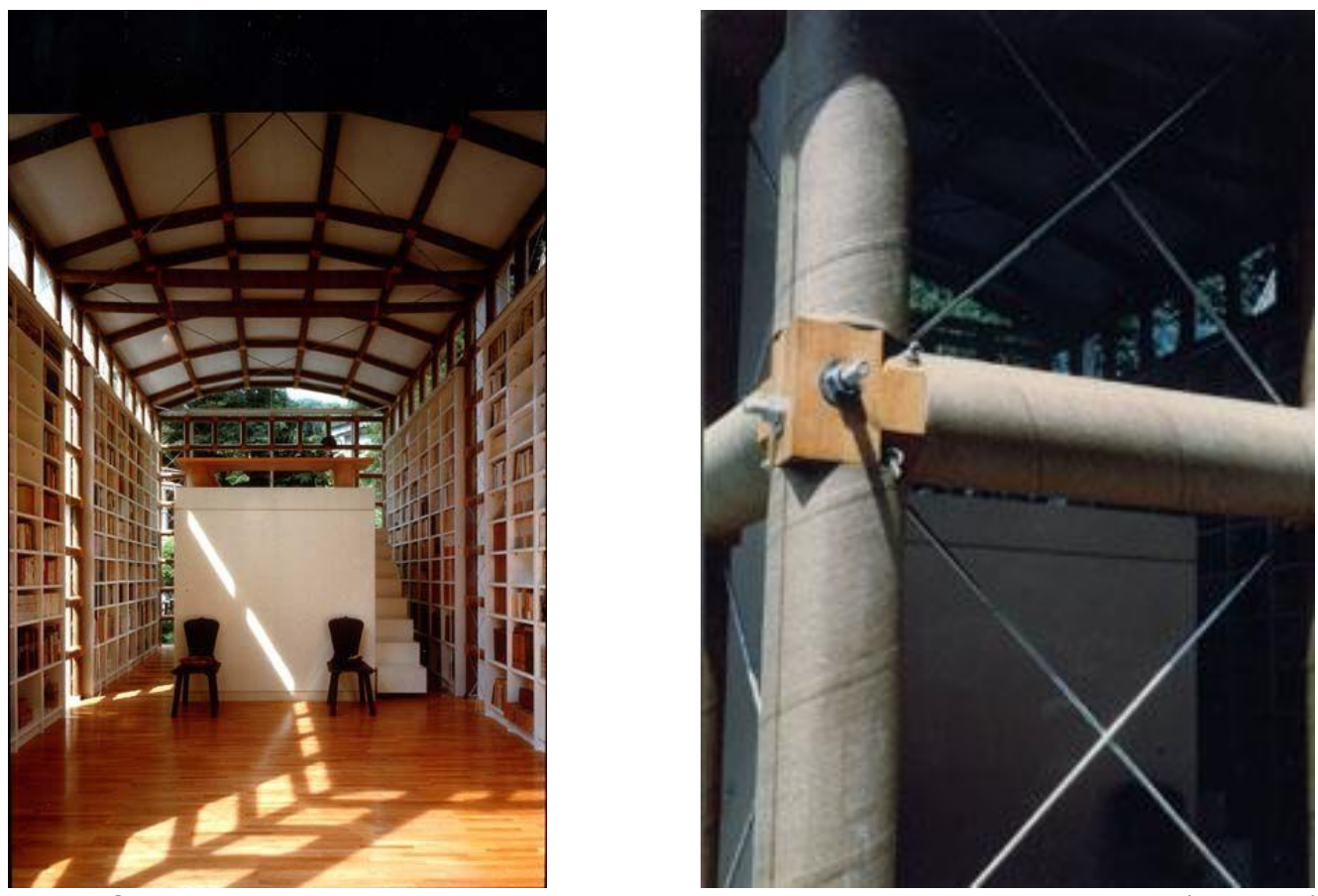

Şekil 14: Şair Kütüphanesi ve bağlantı detayı, Zushi, Kanagawa, Japonya,1991 (URL-15)

\subsection{Japon pavyonu, Almanya, 2000}

Japon Pavyonu, 2000 yılında Hannover Dünya Fuarı için inşa edilmiş ve yedi ay kullanılmıştır. Yapı strüktürü üç boyutlu ızgara kabuk olarak tasarlanmıştır. Strüktür zemine yatırılarak monte edilmiş ve asıl konumuna kaldırılarak lamine ahşap kemerler ile sabitlenmiştir. Üç boyutlu ızgara kabukta kullanılan karton tüpler $120 \mathrm{~mm}$ çapında ve $22 \mathrm{~mm}$ kalınlığındadır. Karton tüplerin kesişim noktaları, esnek kumaşlarla birbirine bağlanmıştır (Şekil 15). Esnek kumaşlar yapıda esnemeye izin vermektedir. 

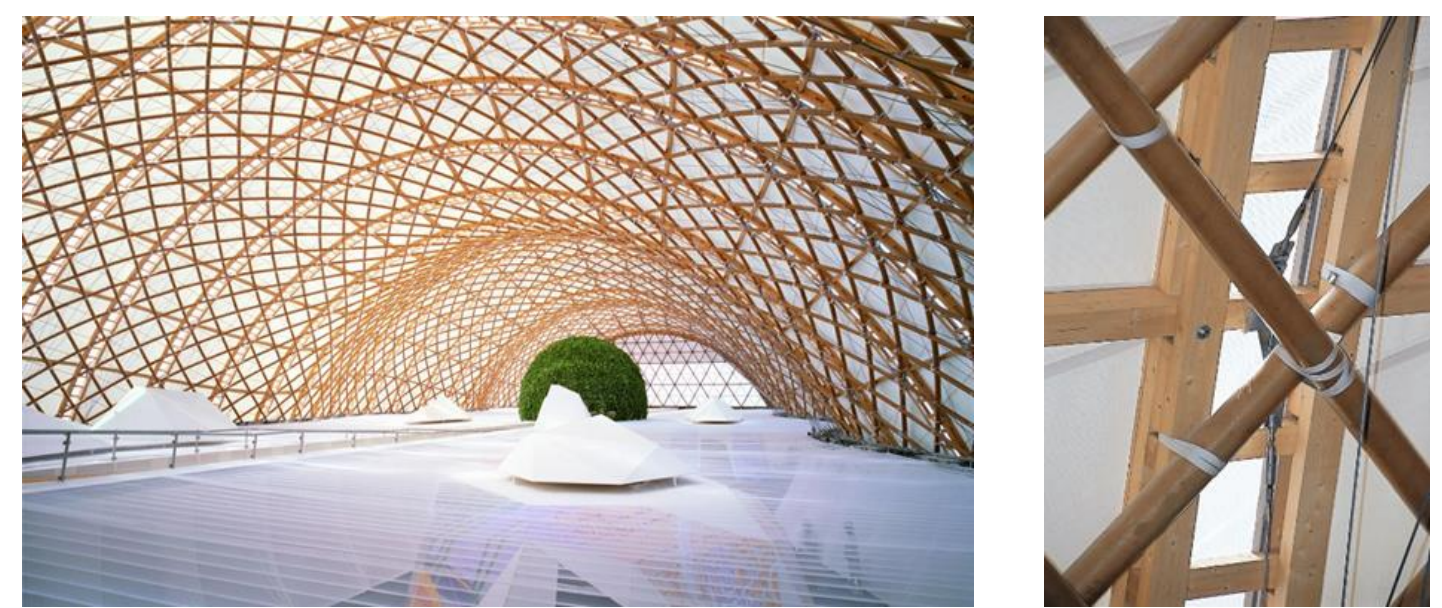

Şekil 15: Japon Pavyonu, Hannover, Almanya, bağlantı noktası, 2000 (URL-16)

Yapının boyutları 35x75 m'dir. Yüksekliği ise 15,5 metreye kadar yükselmektedir (Şekil 16) (Correa, 2004, s. 278). Yapı kâğıt mimarisinin gelişiminde önemli bir aşamadır ve dünyanın başka yerlerinde başka yapıların inşa edilmesine yol açmıştır (URL-16).
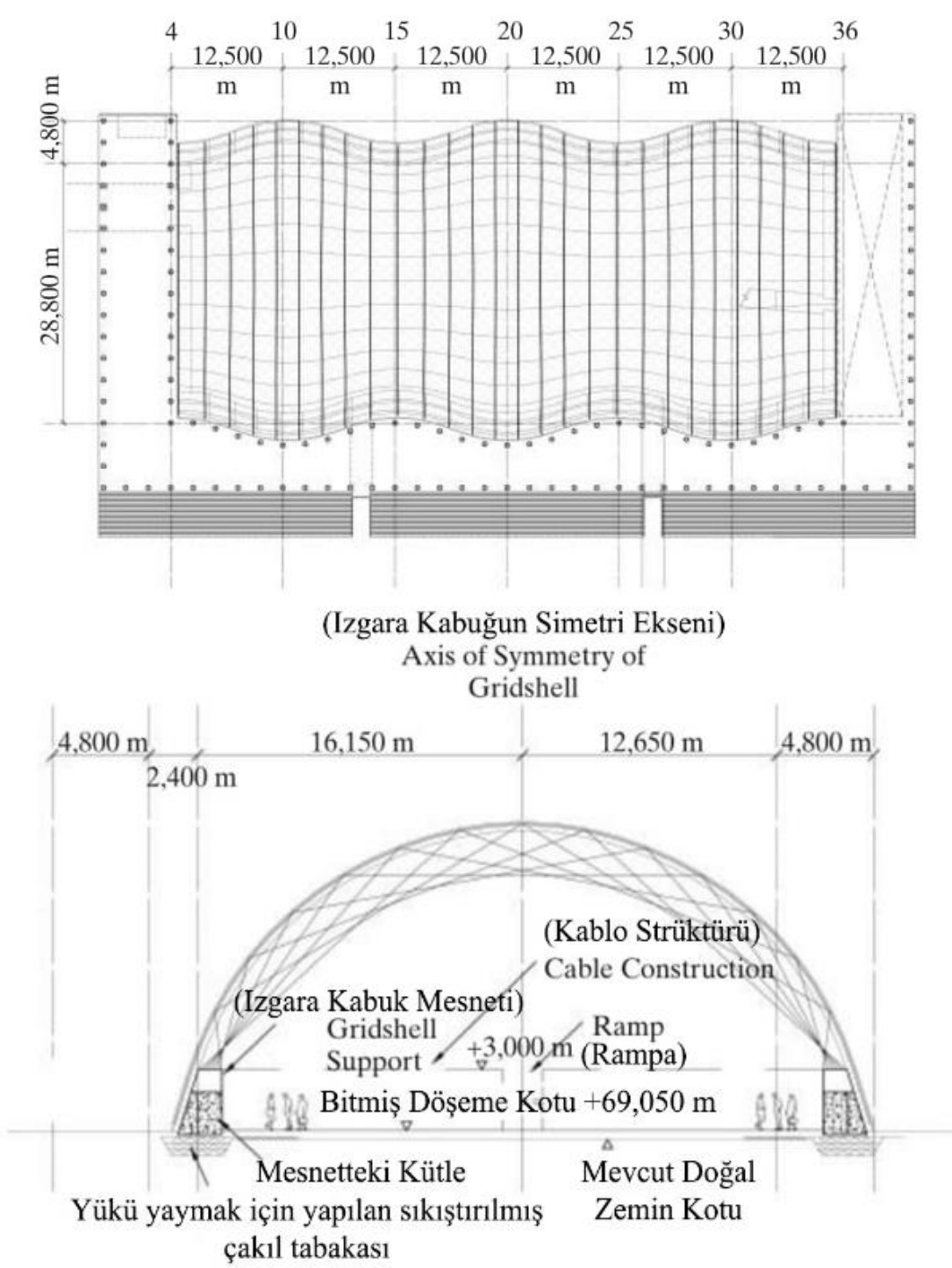

Şekil 16: Japon Pavyonu, Hannover, Almanya, plan, kesit, 2000, (Correa, 2004, s. 278) 
Üretilen karton tüpler, malzemenin kısa ve uzun dönem yapısal performansı hakkında bilgi edinmek üzere Dortmund Üniversitesi'nde test edilmiştir. Malzemenin dayanımı değerlendirmek için gerekli olan güvenlik katsayısı değeri, ahşap yapıların tasarımı için geçerli olan Eurocode 5 (EC5)'ten alınmıştır. Testler karton tüp sistemlerin kısa ve uzun dönemdeki eksenel basınç gerilmeleri ve eğilme momentleri altındaki performanslarını değerlendirmek için yapılmıştır. Yapılan bütün testlerde, malzeme dayanım açısından başarılı bir performans sergilemiştir. Bununla birlikte aleve dayanıklı polietilen bir membranla kaplanmış numunelerin, yangına karşı dayanımlarının artırılabileceği tespit edilmiştir (Latka , 2017, s. 197).

\subsection{Karton katedral, Yeni Zelanda, 2013}

Yapı, Yeni Zelanda'daki Christchurch şehrinde 2011 yılında meydana gelen 6,3 şiddetindeki deprem sonrası, şehrin sembolü olan katedralin yıkılmasının ardından yeni bir katedral olarak tasarlanmıştır. 2013 yılında inşa edilen 700 kişilik kapasiteye sahip olan yapı, ibadet dışında etkinlik ve konser salonu olarak kullanılmaktadır (Şekil 17).

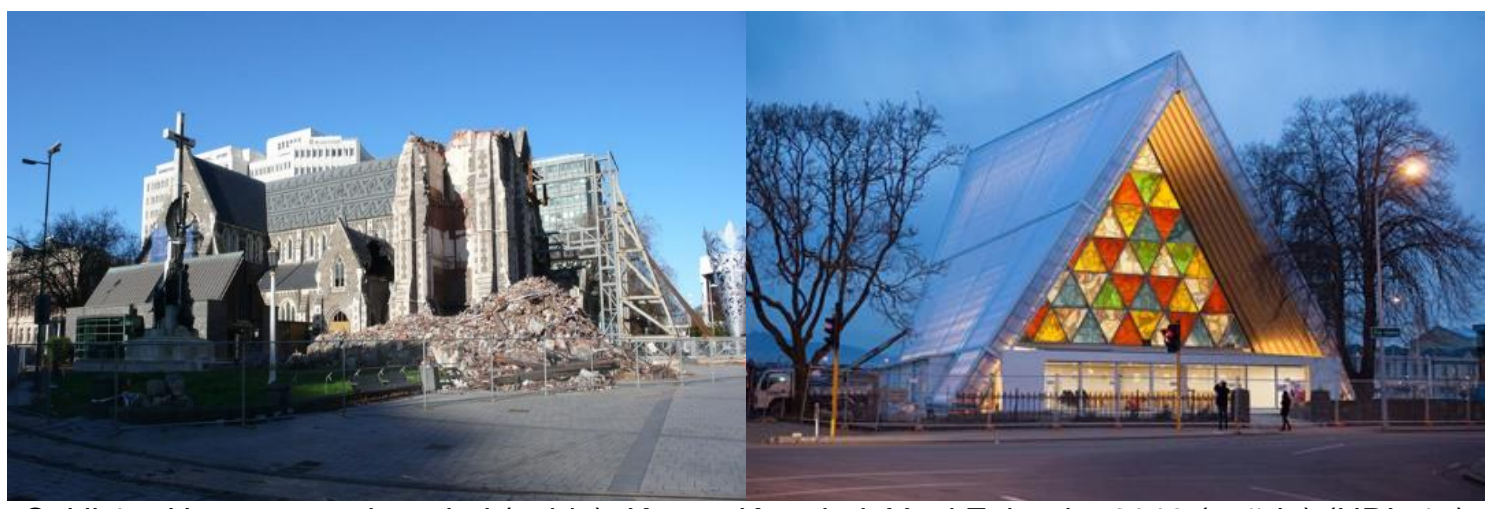

Şekil 17: Hasar gören katedral (solda), Karton Katedral, Yeni Zelanda, 2013 (sağda) (URL-17)

Karton katedral, yıkılan katedrale form olarak sadık kalmıştır. Ancak yıkılan katedralde kullanılan malzeme taştır. Taş yerine kâğıt kullanılması yapıyı oldukça hafifletmiş ve modern bir görünüme kavuşturmuştur. Betonarme bir temele oturan yapıda çatı bileşeni olarak kullanılan 96 adet karton tüp, $60 \mathrm{~cm}$ çapında ve $20 \mathrm{~m}$ uzunluğunda olup poliüretanla yalıtımıştır. Karton tüpler yapının duvarlarını oluşturan konteynerlere sabitlenmiştir. Malzemenin dayanımının yükleri taşıyacak kapasitede olmamasından dolayı karton tüpler lamine ahşap kirişlerle desteklenmiştir. Karton tüplerin iç mekânda ayırıcı ve mobilya olarak kullanılmasıyla da yapı tasarımı bütünleştirilmiştir. Cephede kullanılan vitraylarsa manevi duyguları güçlendirmektedir (Şekil 18) (Bulut \& Gürani, 2018, s. 154-155).
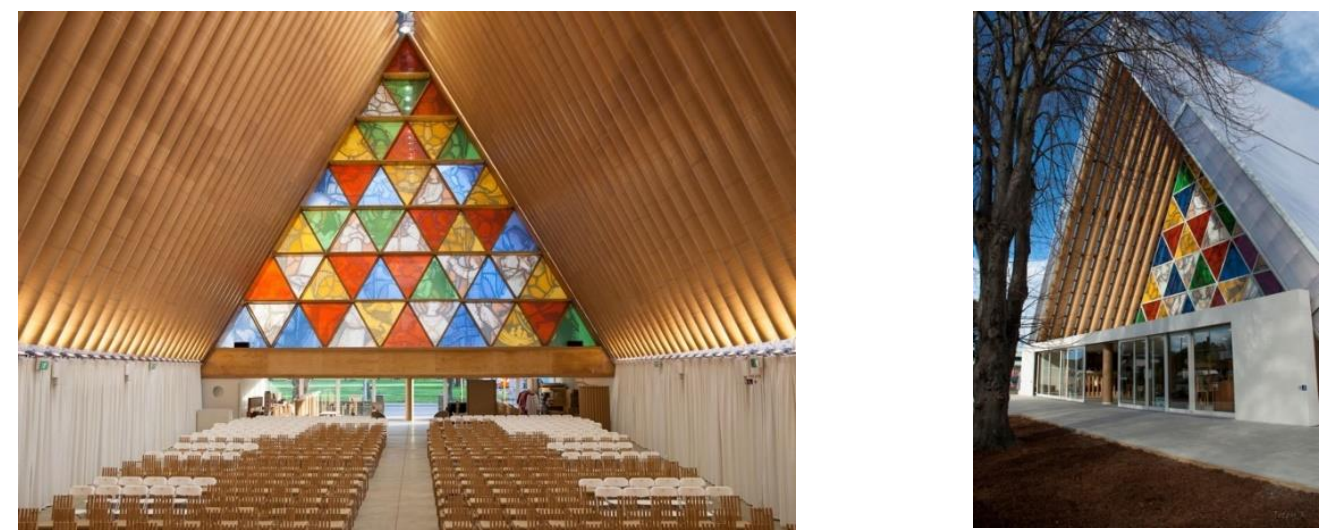

Şekil 18: Karton Katedral, Yeni Zelanda, 2013 (URL-17) 


\subsection{Kâğıt ev, geçici deprem konutları (Kobe, Japonya-1995, Düzce, Türkiye-2000, Bhuj, Hindistan-2001)}

17 Ocak 1995 'te Japonya'da meydana gelen 7,2 şiddetteki deprem sonrası, Kobe ve yakınlarındaki bölgelerin neredeyse tamamı yıkılmıştır. İnşa edilen geçici barınakların duvar ve çatı bileşeninde geri dönüştürülebilir karton tüpler kullanılmıştır. Poliüretan bazlı vernikle kaplanarak suya karşı yalıtılan karton tüpler, yaklaşık olarak aynı boyutlarda olan ahşap yapısal elemanın taşıyacağı yükün yarısını taşıyabilmektedir (Tüzün, 2002, s. 62-63). 108mm çapında ve $4 \mathrm{~mm}$ kalınlığındaki karton tüplerden oluşan bir barınağın alanı 16 metrekaredir. Temel sistemi olarak kum dolu çuvallar yerleştirilmiş kasalar kullanılmıştır. Dört kişi için tasarlanan barınak, 6 saatte inşa edilebilmektedir. Karton tüplerin birleşim yerlerine yalıtım amacıyla su geçirmez bant yapıştırımıştır. Barınağın çatı strüktürü de karton tüplerden oluşmaktadır ve üzeri su geçirmez bir örtüyle kaplanmıştır (Şekil 19).
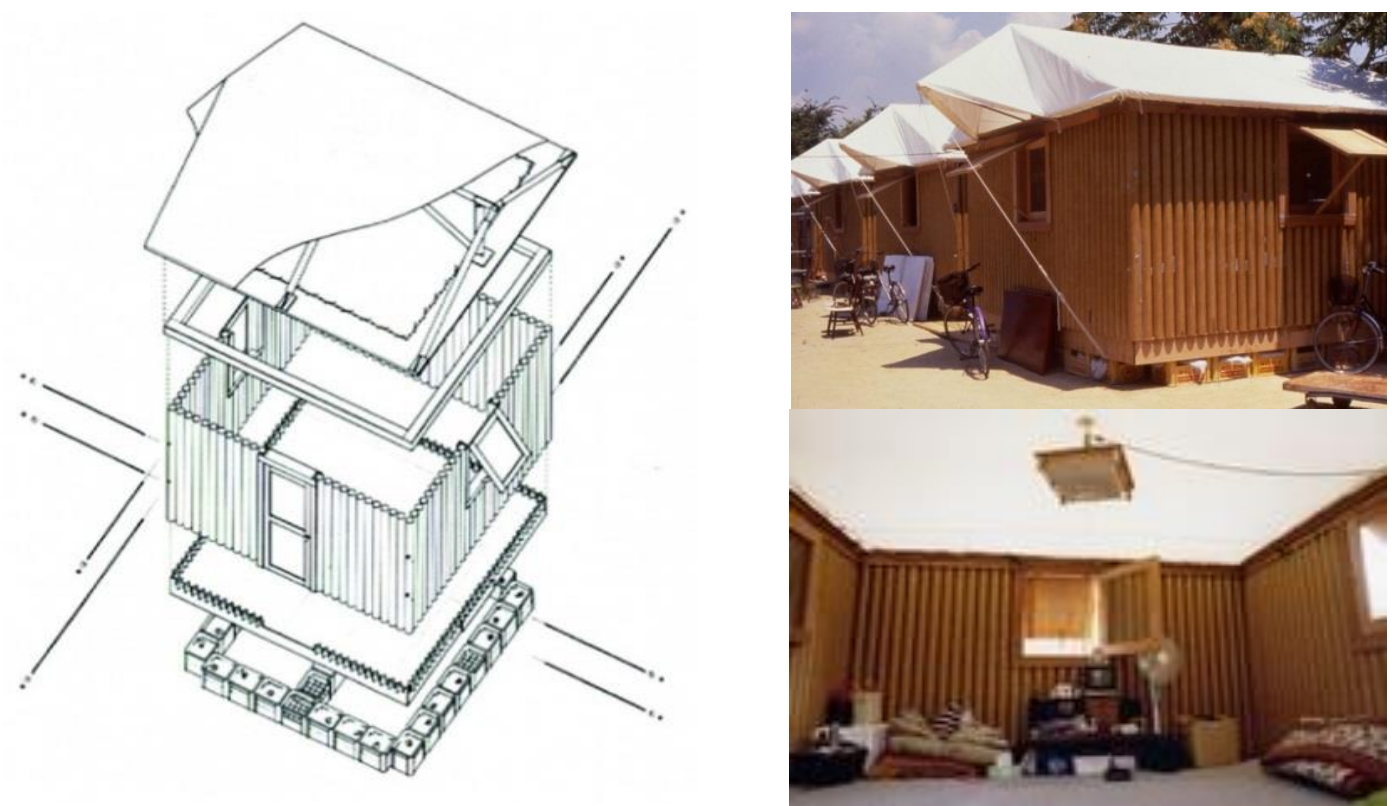

Şekil 19: Geçici kâğıt ev, Kobe, Japonya, 1995 (URL-18) (URL-19)

17 Ağustos 1999 yılında, merkez üssü Gölcük olmak üzere Marmara Bölgesi 7,4 büyüklüğündeki depremle sallanmış, büyük can ve mal kayıpları oluşmuştur. $12 \mathrm{Kas} ı$ m 1999'da saat 18:58'de Bolu'nun Düzce ve Kaynaşı bölgesinde olan 7,2 büyüklüğündeki deprem sonrası binlerce kişinin evsiz kalmasıyla afetin etkisi daha da ağırlaşmıştır.

Uzun süreli barınma intiyacı için tasarlanan kalıcı konutların inşasının uzun bir süre gerektirmesi geçici barınma intiyacı ortaya çıkarmıştır. 2000 yılında Düzce'de inşa edilen karton tüp barınaklarla bu intiyaç karşılanmaya çalışılmıştır. Geçici barınaklar, Kobe depremi sonrası inşa edilen barınaklarda kullanılan karton tüplerin, duvar ve çatı bileşeni olarak kullanımıyla benzerlik göstermektedir. Türkiye İstatistik Kurumu (TUIKK) 2000 yılı verilerine göre ortalama hanehalkı sayısının 4,5 olduğu (Pekuzun, 2021, s. 29) ve kişi başına düşen alanın $3,5-4,5 \mathrm{~m}^{2}$ arasında gerektiği düşünülerek, barınak alanı olarak Kobe'dekinden daha büyük olan 3mx6m plan boyutları seçilmiştir. Kâğıdın hammaddesi olan selülozun, ısı iletkenlik katsayısının $\lambda=0,038 \mathrm{~W} / \mathrm{mK}$ olması (Manasoğlu, 2014, s. 2) malzemenin ısı geçirimliliğe karşı ciddi bir direnç göstermesine sebep olmaktadır. Karton tüplerin içinin atık kâğıtlarla dolduruımasıyla ısı yalıtımının sağlanması amaçlanmıştır (Şekil 20). 

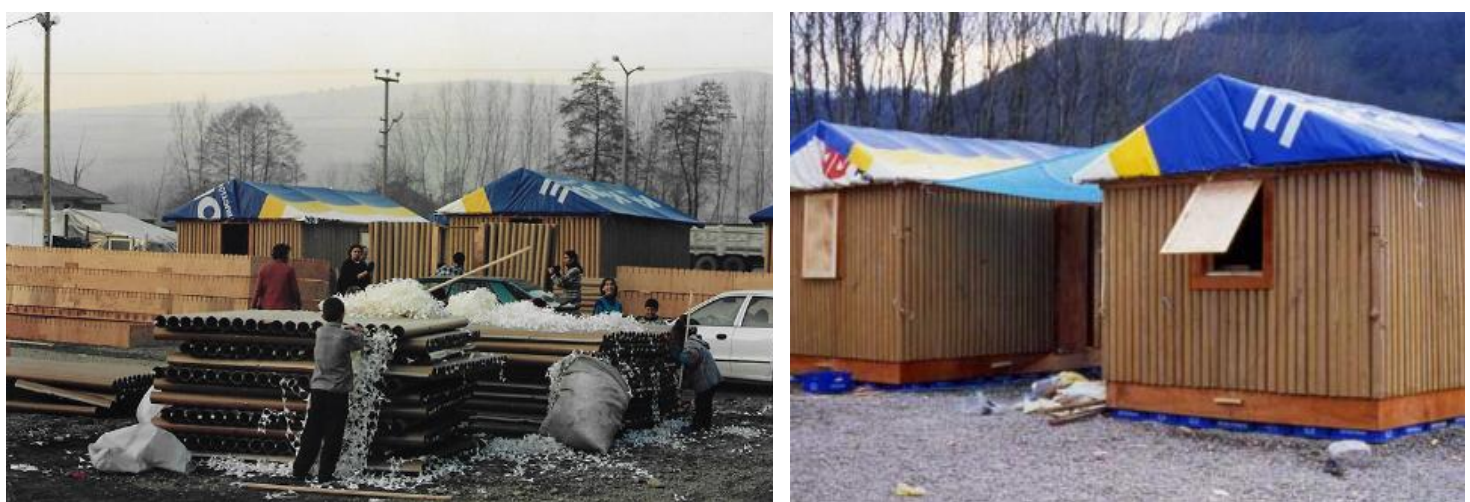

Şekil 20: Geçici kâğıt ev, Düzce, Türkiye, karton tüplerin atık kâğıtlarla doldurulması, 2000 (URL-20) (URL-21)

26 Ocak 2001 'de Hindistan'ın Gujarat eyaletinde çok sayıda can kaybı ve yaralanmalara yol açan 7,7 büyüklüğünde bir deprem meydana gelmiştir. Depremin etkisiyle 300.000'den fazla bina yıkılmış ve 700.000'den fazla bina ağır hasarlı duruma gelmiştir. Geçici barınma intiyacı için tasarlanan barınak, Kobe ve Düzce'de inşa edilen geçici konutlardan temel ve çatı konstrüksiyonu olarak farklılık göstermektedir. Barınağın temelinde, içi kum dolu çuvallarla doldurulmuş kasalar yerine deprem sonrası oluşan molozlar kullanılmış ve molozların üzeri geleneksel toprak zeminle kaplanmıştır. Bambu kamışlarından oluşturulan çatı strüktürünün üzeri muşamba ile örtülmüştür. Doğal havalandırma için karton tüplerin birleşimlerinde boşluklar bırakılmıştır. Geçici barınaklar derslik olarak da kullanılmıştır (Şekil 21).
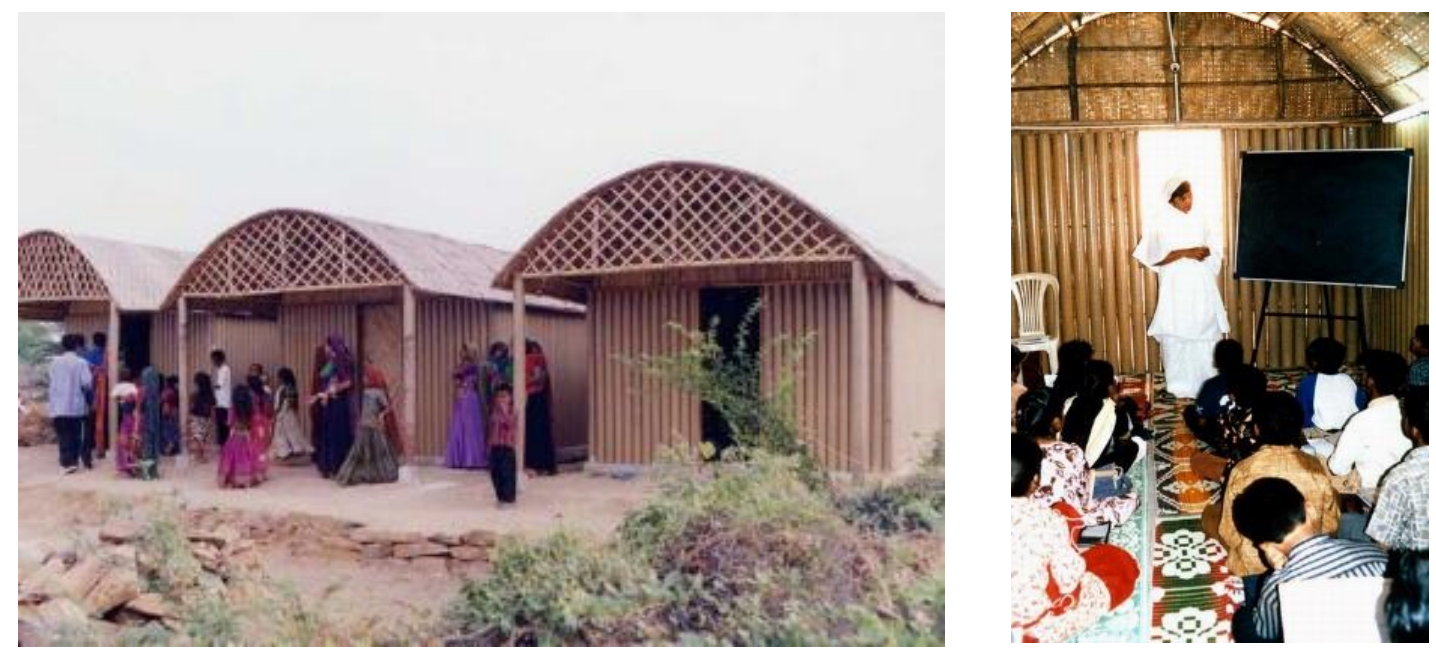

Şekil 21: Geçici kâğıt ev - Bhuj, Hindistan, derslik, 2001 (URL-22)

Shigeru Ban'ın karton tüp sisteme sahip önemli eserleri; yapının yeri, yapım yılı, karton tüp sistemin işlevi, plan boyutları ve kısa bilgi başlıkları altında Tablo 1'de sunulmuştur 
Tablo 1. Shigeru Ban'ın bazı önemli eserleri (URL-23)

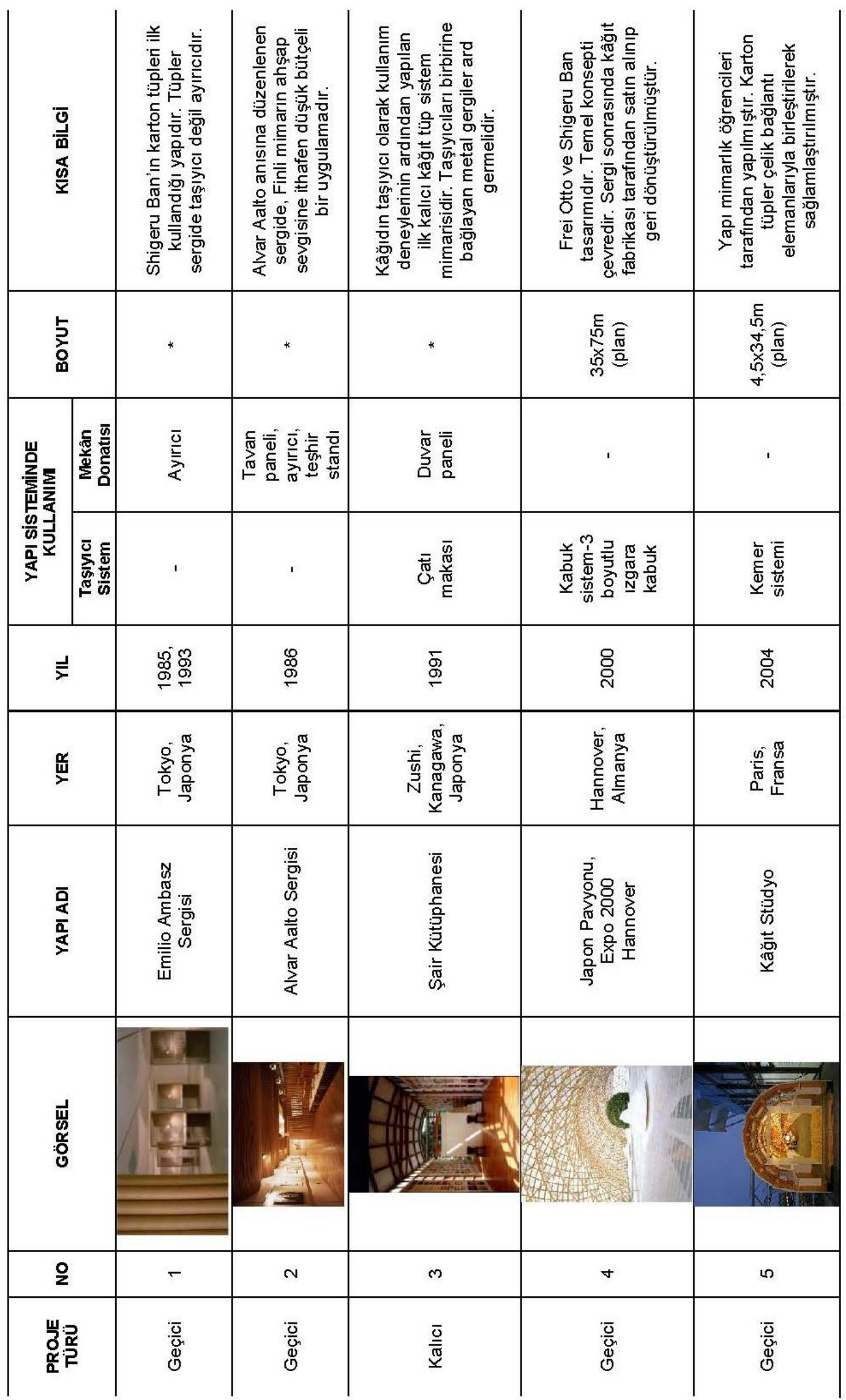


Tablo 1. Shigeru Ban'ın bazı önemli eserleri (URL-23)

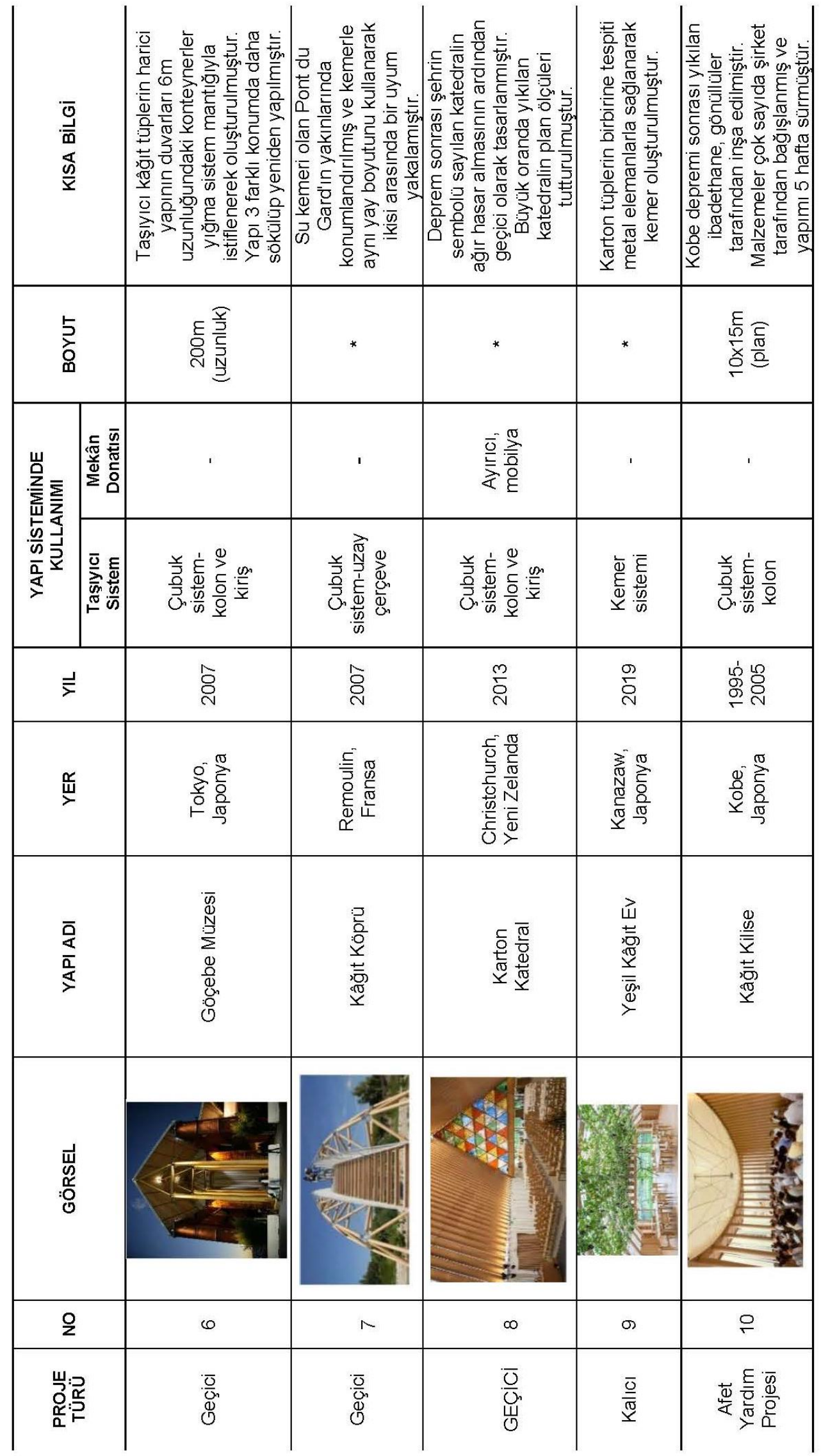


Tablo 1. Shigeru Ban'ın bazı önemli eserleri (URL-23)

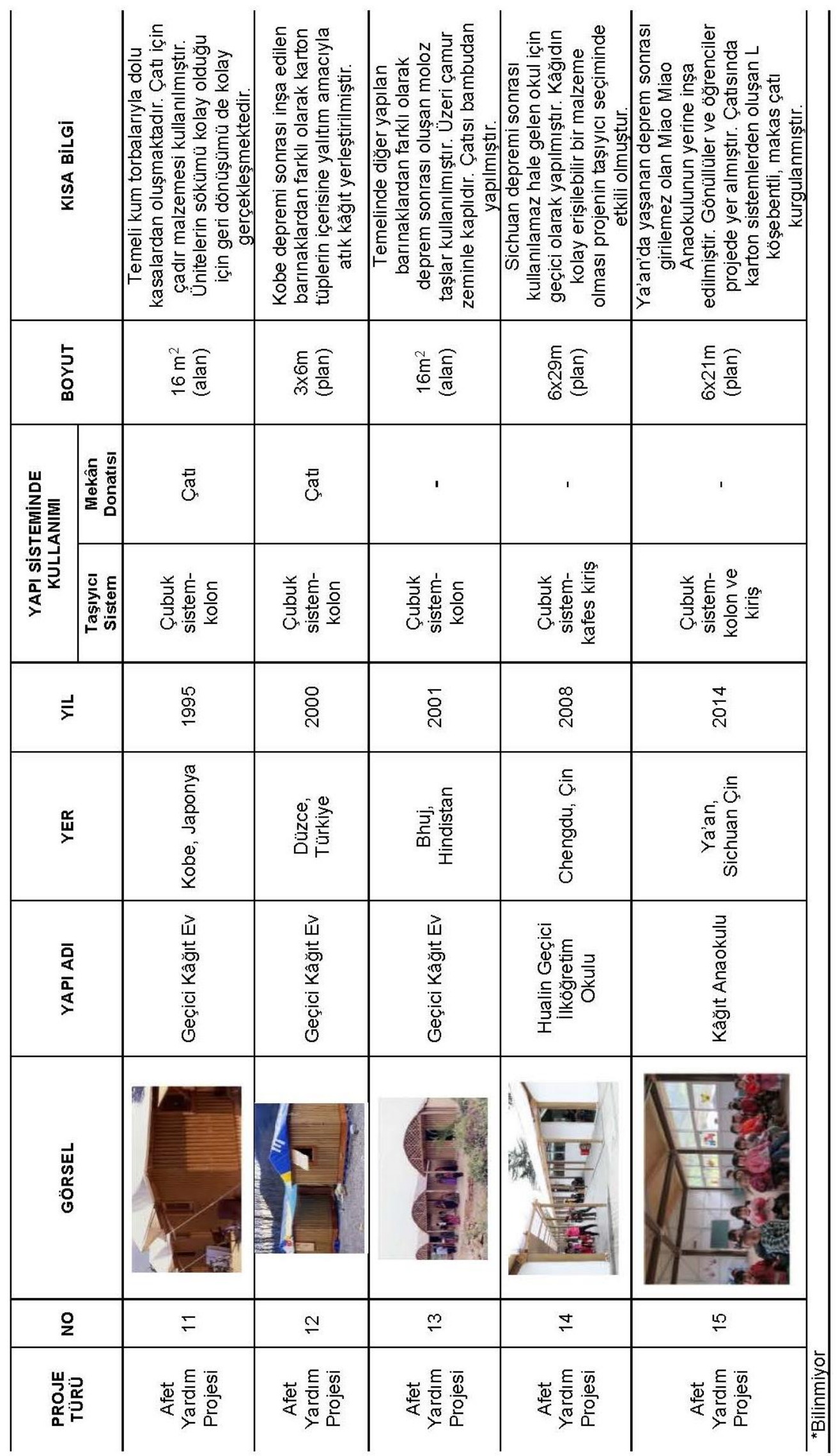




\section{Değerlendirme ve Sonuç}

Karton tüp sistemlerin geçmişi, kâğıdın deneysel yaklaşımlarına dayanmaktadır. Japonya'nın kâğıt yapım tekniklerini geliştirmesi ve kâğıdın yapılarda bölücü eleman olarak kullanılması mimari için öncü bir yaklaşım oluşturmuştur. Kâğıdın ekonomik ve hafif oluşu evlerde kullanımını denemek için fırsat görülmüştür. Gelişimine evlerde devam eden kâğıt bu süreçte mimaride farklı kullanımlarını oluşturmuştur. Daha sonra yaşanan 2. Dünya savaşı sonrası Amerika ve Avrupa'da yaşanan konut sıkıntısı sonrası geçici barınaklarda kullanılmaya başlanmıştır. Kâğıt bu şekilde mimaride hem kalıcı hem de geçici olarak kullanımına yönelik denemelerden geçmiştir.

1980'ler sonrası kâğıdın çağdaş anlamda kullanımı Shigeru Ban ile gerçekleşmiştir. Ban, kâğıdı ilk sergisinde bölücü olarak karton tüp şeklinde kullanmıştır. Ban, karton tüpleri daha da yakından inceleyerek, mimaride taşıyıcı olarak kullanılma olasılığı üzerine çalışmalarda bulunmuş ve bu araştırmalar sonucunda ilk kalıcı yapı olan "Şair Kütüphanesi'ni inşa etmiştir. Ban tasarımın ekonomik, kolay hayata geçirilebilir ve dayanıklı olması gerektiğini düşünen bir mimardır. Bu bağlamda çalışmalarına devam ederek karton tüpleri mimaride farklı sistemlerde kullanmayı başarmıştır. Ban'ın afet sonrası ortaya çıkan geçici konut intiyacı için planladığı karton tüp barınaklar; ekonomik olmaları, hızlı inşa edilebilmeleri, etkili ısı yalıtımları ve geri dönüştürülebilir malzemeden üretilebilmeleri sebebiyle tek katlı, yaklaşık $6 \mathrm{~m}$ açıklık geçen geçici barınma intiyacı için iyi bir alternatiftir. Örneklerde verildiği gibi müze, dini yapı ve köprü gibi uygulamalarda özel birleşim detayları ve artırılmış malzeme kesitleriyle açıklık ve kat yüksekliğini artırarak daha büyük mekânlar oluşturmak mümkündür.

Karton tüp sistemlerin sistemin yangına, suya ve atmosferik diğer etkilere karşı dayanımı için özel önlemler gerektirmesi ve maliyetinin artması malzemenin sınırlarını oluşturmaktadır. Proje bazlı gereken yüksek dayanım değerleri için üreticilerle irtibata geçilmesi ve özel üretim yapılması gerekmektedir. Bu sistemler ile alakalı bir tasarım yönetmeliğinin olmaması sebebiyle ahşap yapıların tasarımı için geçerli olan EC5 gibi yönetmeliklerden faydalanılmaktadır. Bununla birlikte sistemin tasarımı basit mukavemet hesapları ile yapılabilmektedir.

Ülkemizde karton tüp sistemlerin gelişimi maliyet ve teknoloji ile doğrudan irtibatıdır. Türkiye şartlarında malzeme olarak "kâğıt" değerlendirildiğinde karşılaşılan tablo ahşap malzeme ile benzerdir. Her iki malzemenin de kaynağı endüstriyel ormanlara bağlıdır. Ülkemizde özellikle son 50 yılda inşa edilen yapılarda betonarme taşıyıcı sistemin tercih edilmesiyle yapısal ahşap üretimi azalmış, maliyetler artmış ve kâğıt için gerekli olan hammadde üretimi de azalmıştır. Bunun sonucunda kâğıt makinelerindeki yeni teknolojilerin takip edilmemesi, işletme giderlerinin fazlalığı maliyeti yüksek kılmakta ve kâğıdın mimaride kullanımına sınırlama oluşturmaktadır.

Marmara Depremi sonrası Düzce'de inşa edilen geçici barınaklar karton tüp sistemlerin ülkemizde mimaride uygulanan bir örneğidir. Ülkemizdeki yıkıcı depremlerin sıklığı ve hızıı bir şekilde inşa edilmesi gereken geçici konut intiyacı düşünüldüğünde karton tüp sistemler ülkemiz için alternatif bir yapı malzemesidir. Endüstriyel orman yönetimi ile malzemenin maliyetinin ekonomik hale getirilmesi sistemin sadece afet sonrası kullanılan yapılar için değil literatürde örnekleri verildiği gibi mimaride çeşitli işlevlerdeki yapılar için de kullanılabileceğini göstermektedir.

Yapı sektörü çevreye karşı sorumluluğu yüksek olan sektörlerden biridir. Ülkemizde inşaat atıklarının çoğu vahşi depolanmakta (kontrolsüz çöplük) ve bu durum geri dönüştürülebilir malzeme kullanımının gerekliliğini ortaya çıkarmaktadır. Özellikle atık 
kâğıtların yapı sektörüne hammadde olarak girişinin sağlanması günümüz Türkiye'si için hem geri dönüşümdeki payımızı artıracak hem de döngüsel ekonomiye katkı sağlayacaktır. Karton tüp sistemlerde kullanılan kâğıdın durabilite ve mekanik özelliklerinin geliştirilme amacıyla laminasyon, katkı ve püskürtme gibi tekniklerle kullanılması malzemenin tamamıyla geri dönüştürülebilirliğini olumsuz etkilemektedir. Özellikle geçici yapılarda kullanılacak yüzde yüz geri dönüşümlü kâğıdın geri kazanımıyla tükenmekte olan kaynaklarımızın da etkin kullanılacağı düşünülmektedir.

\section{Kaynaklar}

Akpınar, C. (2011). Kağıt Endüstrisinde Kullanılan Bobin Kesme Makinesinin İncelenmesi Ve Modellenmesi. (Yüksek lisans tezi). Yıldız Teknik Üniversitesi, Fen Bilimleri Enstitüsü, İstanbul.

Baer, S. (2009). Some Passive Solar Buildings with a Focus on Projects in New Mexico. A.I.o. Architects, Editor.

Bank, L. C. \& Gerhardt, T. D. (2016). Paperboard tubes in structural and construction engineering. K. H. Sharma içinde, Nonconventional and Vernacular Construction Materials, Atlanta, GA, United States: Woodhead Publishing, 453-480.

Bikçe, M. (2016). A database for fatalities and damages due to the earthquakes in Turkey (1900-2014). Nat Hazards, 83:1359-1418.

Bikçe, M. (2017). Türkiye'deki Depremlerde Alınan ve Alınabilecek Önlemler. Uluslararası Mühendislik Araştırma ve Geliştirme Dergisi, 9 (2), 24-31.

Bulut, D. M. \& Gürani, F. Y. (2018). A Study Of Shigeru Ban's Environmentally Sensitive Architectural Design Approach. Gazi University Journal of Science Part B: Art Humanities Design and Planning, 6 (3), 147-157.

Campean, T., Peiu, N. \& Gavrilescu, M. (2020). Alternative Uses Of Paper And Cardboard In Architecture And Construction. Buletinul Institutului Politehnic Din Iaşi, Volumul 66 (70), 9-29.

Correa, C. (2004). Designing with Paper Tubes. Structural Engineering International, 14(4):277-281.

Engel, H. (1985). Measure and Construction of the Japanese House. Singapore: TUTTLE Publishing.

İçemer, S. P. (2015). İç Mekan Tasarımında Modüler Seramik Seperasyonlar. (Yüksek lisans sanat çalışması raporu). Hacettepe Üniversitesi, Güzel Sanatlar Enstitüsü, Ankara.

Karni, E. \& Pellegrino, S. (2007). A Retractable Small-Span Roof Based on Thin-Walled Lightweight Spatial Units. International Journal of Space Structures. 22 (2), 93-106.

Kurnalı, M. (2015). İç Mekanda Prefabrikasyon ve Günümüz Prefabrik İç Mekan Ürünlerine Yönelik Bir İnceleme. (Yüksek lisans tezi). Hacettepe Üniversitesi, Güzel Sanatlar Enstitüsü, Ankara. 
Latka , J. (2017). Paper in Architecture: Research by Design, Engineering and Prototyping. Delft: Faculty of Architecture and the Built Environment, Delft University of Technology.

Manasoğlu, G. (2014). Selüloz Tozlarının Tekstil Kaplamacılığında Kullanımı Üzerine Bir Araştırma. (Yüksek lisans tezi). Uludağ Üniversitesi, Fen Bilimleri Enstitüsü, Bursa.

Pekuzun, E. (2021). Türkiye'de Hanehalkı Büyüklüğündeki Değişimin İller Düzeyinde Analizi ve Geleceğe Dönük Bir Projeksiyon. (Yüksek lisans tezi). Karabük Üniversitesi, Lisansüstü Eğitim Enstitüsü, Karabük.

Schonwalder, J. (2016). Cardboard as Building Material. TU München: Tentech BVEngineering Consultancy of Lightweight structures Utrecht. Faculty of Architecture T.U. Delft.

Tüfenk, M. T. (1989). Türkiye'de Kağıt Sektörü ve Gelişimi. (Yüksek lisans tezi). İstanbul Üniversitesi, Sosyal Bilimler Enstitüsü, İstanbul.

Tüzün, E. (2002). Ev/Yaşama Mekanı: Afet Sonrası Gereksinimler. (Yüksek lisans tezi). İstanbul Teknik Üniversitesi, Fen Bilimleri Enstitüsü, İstanbul.

Yazoo Mills, Inc. (2019). A Beginner's Guide on How Paper Tubes \& Cores are Manufactured. United States: Yazoo Mills, Inc.

URL-1. 25 Haziran 2021 tarihinde

https://shojijarchitecture.wordpress.com/2020/11/12/minka-evleri/ adresinden alındı

URL-2. 25 Haziran 2021 tarihinde

http://artehistoriaestudios.blogspot.com/2018/12/capitulo-4-japon-modernotemprano.html adresinden alındı

URL-3. 3 Şubat 2021 tarihinde http://www.paperhouserockport.com/ adresinden alındı

URL-4. 3 Şubat 2021 tarihinde https://www.iqsdirectory.com/cardboard-tubes/ adresinden alındı

URL-5. 5 Şubat 2021 tarihinde https://www.pakea.eu/en/activites-paperconverting/paper-tubes-and-cores-production-lines/ adresinden alındı

URL-6. 5 Şubat 2021 tarihinde https://www.mailing-tube.com/custom.php adresinden alındı

URL-7. 5 Şubat 2021 tarihinde https://my.all.biz/tube-winder-belt-g50607 adresinden alındı

URL-8. 5 Şubat 2021 tarihinde https://www.amortech3d.com/buy-high-qualitycardboard-tubes-for-packaging-online-at-wholesale-prices/ adresinden alındı

URL-9. 5 Şubat 2021 tarihinde https://www.sonotube.com/aboutus.aspx adresinden alındı

URL-10. 5 Şubat 2021 tarihinde

https://www.sonotube.com/sonovoidroundconcreteforms.aspx adresinden alındı 
URL-11. 5 Şubat 2021 tarihinde

http://www.shigerubanarchitects.com/works/2011_paper-concert-hall/index.html adresinden alındı

URL-12. 7 Şubat 2021 tarihinde Visita al Paper Pavilion, del arquitecto japonés Shigeru Ban, Artediez: https://artediez.es/interiores/visita-al-paper-pavilion-del-arquitectojapones-shigeru-ban-premio-pritzker-2014/ adresinden alındı

URL-13. 5 Şubat 2021 tarihinde

http://www.shigerubanarchitects.com/works/2009_hong-kong-biennalepavilion/index.html adresinden alındı

URL-14. 7 Şubat 2021 tarihinde

http://www.shigerubanarchitects.com/works/1990_odawara-hall-and-eastgate/index.html adresinden alındı

URL-15. 7 Şubat 2021 tarihinde

http://www.shigerubanarchitects.com/works/1991_library-of-a-poet/index.html adresinden alındı

URL-16. 7 Şubat 2021 tarihinde Detail Inspiration: https://inspiration.detail.de/japanesepavilion-at-the-expo-in-hanover-106867.html?lang=en adresinden alındı

URL-17. 7 Şubat 2021 tarihinde https://www.arkitera.com/haber/mukavvadan-katedralolur-mu-demeyin/ adresinden alındı

URL-18. 7 Şubat 2021 tarihinde https://www.architectmagazine.com/projectgallery/paper-log-house-kobe adresinden alındı

URL-19. 7 Şubat 2021 tarihinde https://www.urbanews.fr/2013/10/09/36324-shigeruban-ville-en-carton-ville-recyclee-ville-preparee/\#jp-carousel-36333 adresinden alındı

URL-20. 7 Şubat 2021 tarihinde

http://www.shigerubanarchitects.com/works/2000_paper-log-house-turkey/index.html adresinden alındı

URL-21. 7 Şubat 2021 tarihinde https://www.mozaikdesign.com/en/contracts/kagittanevler/ adresinden alındı

URL-22. 7 Şubat 2021 tarihinde Jain religious leader teaching children, Paper Loghouse: https://archnet.org/sites/5102/media_contents/38396 adresinden alındı

URL-23. 12 Şubat 2021 tarihinde http://www.shigerubanarchitects.com/works.html adresinden alındı 